\title{
Atmospheric and Oceanic Variability in the Northwest Atlantic During the 1980s and Early 1990s
}

\author{
K.F. Drinkwater \\ Department of Fisheries and Oceans, Ocean Sciences Division \\ Bedford Institute of Oceanography, Dartmouth, Nova Scotia, Canada B2Y 4A2
}

\begin{abstract}
A review of atmospheric and oceanographic conditions in the northwest Atlantic during the 1980s and early 1990s is presented based upon standard station data and climate indices. Air temperatures over Baffin Bay and the Labrador Sea were generally cold in contrast to warm conditions along the Middle Atlantic Bight. These are linked to the largescale atmospheric circulation patterns which produced strong northwest and southwest winds, respectively, over the two regions. The cold air masses and strong northwest winds in the northern regions resulted in more extensive sea ice coverage than normal. Extremely cold ocean temperatures were observed in the Grand Banks region and contrast with the warm temperatures in the deep waters in shelf regions further south. Ocean climate variability has been found to be influenced not only by local atmospheric forcing but also by the advection of water from upstream. Offshore exchange between the slope and shelf waters is a believed to be the primary mechanism for climate changes from the Laurentian Channel to the Middle Atlantic Bight.
\end{abstract}

Key words: Atmosphere, climate, oceanography, NW Atlantic, temperatures

\section{Introduction}

This paper reviews physical environmental conditions within the NAFO area of the Northwest Atlantic with special emphasis upon the waters over the continental shelves off West Greenland, eastern Canada and the northeastern United States. Temporally, the focus is on the decade of the 1980s and the first few years of the 1990s. Atmospheric, sea-ice, hydrological and oceanic data are described, comparisons made with past conditions, teleconnections between variables explored and forcing mechanisms discussed. The 1980s and early 1990s have been important climatologically because of severe cold conditions in northern waters and biologically because of significant changes to several important fish and shellfish stocks in the Northwest Atlantic. For example, the abundance of certain major demersal fish stocks, such as Atlantic cod (Gadus morhua), declined to the point of commercial collapse while at the same time historic high levels of landings of American lobster (Homarus americanus) were recorded. Climate fluctuations have been suggested as being at least partially responsible for the changes in cod and lobster stocks.

Much is already known about interannual variability in environmental conditions during the 1980 s and early 1990s from annual reviews presented to NAFO from 1982 (Trites and Drinkwater, 1984) to the present (Drinkwater et al., MS 1995) and from regional studies (West Greenland: Buch and Stein, 1989; Stein, 1993; Newfoundland and Labrador: Petrie et al., 1992; Colbourne et al., 1994; Gulf of St. Lawrence: Gilbert and Pettigrew, 1996; Scotian Shelf and Gulf of Maine: Petrie and Drinkwater, 1993; Gulf of Maine and Middle Atlantic Bight: Mountain and Murawski, 1992). The present paper draws upon the results of these studies and provides new analyses, including a focus upon decadal changes and an attempt to synthesize the results from the various studies by emphasizing regional similarities and differences.

The NAFO area spans $40^{\circ}$ of latitude and $30^{\circ}$ of longitude (Fig. 1). Over such a large area, it is not surprising that interannual and decadal fluctuations vary as a result of differences in atmospheric, hydrological and oceanographic (deep sea) forcing. However, important linkages do occur between areas because of advection by the mean currents. A brief review is therefore given first of the oceanic circulation patterns in the NW Atlantic. This is followed by a description of the climatological data and statistical methods used in this study. The longterm variability in atmospheric conditions, including air temperatures, air pressures and winds is then discussed. Sea ice and hydrological conditions are described afterwhich changes in hydrographic 


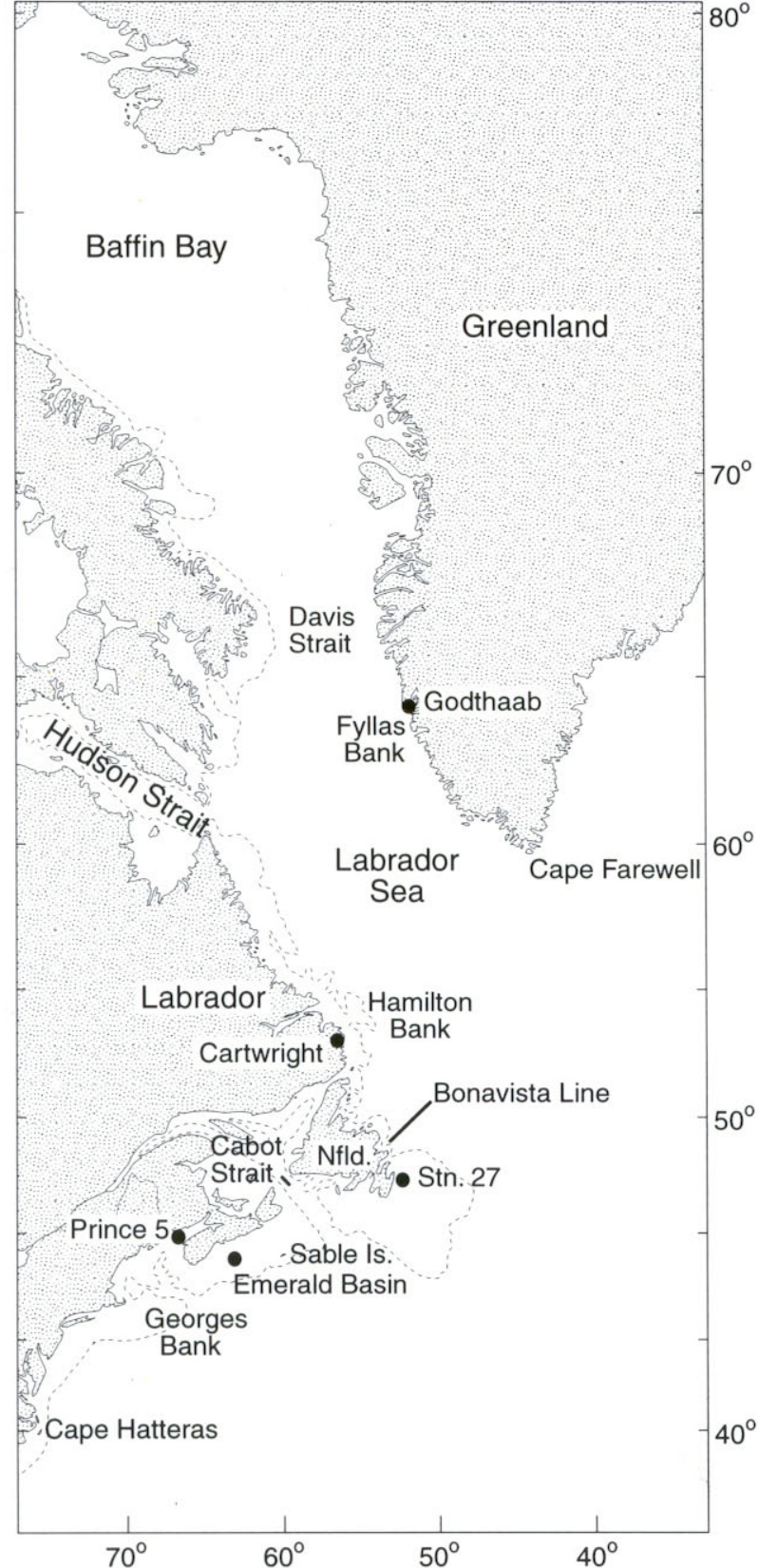

Fig. 1. The NW Atlantic study area.

properties are presented, region by region. The last section provides a summary of the results, compares and contrasts regions, and highlights some significant advancements made in our knowledge since the last decadal review (NAFO, 1982).

\section{General Circulation}

The West Greenland Current flows northward along the west coast of Greenland (Fig. 2). The shelf

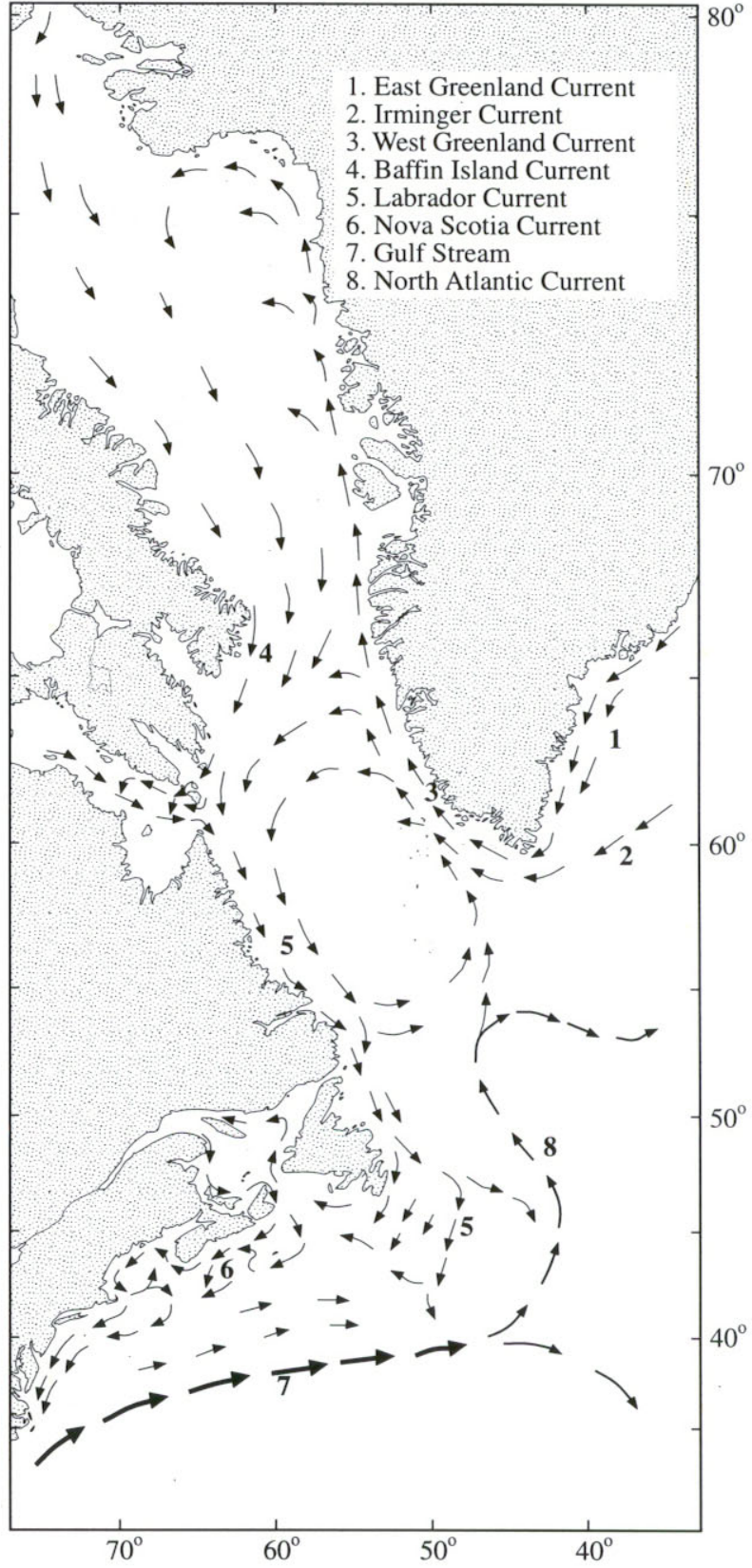

Fig. 2. The near surface circulation pattern in the NW Atlantic.

component is an extension of the relatively cold East Greenland Current while the warmer offshore component along the continental slope is feed by the Irminger Current and the North Atlantic Current (Buch, 1994). The majority of the transport branches westward prior to reaching Davis Strait but a small inshore component continues north into Baffin Bay. There it meets and mixes with Arctic waters flowing through Nares Strait to form the Baffin Island Current. This current flows southward in western 
Baffin Bay and enters the Labrador Sea inshore of the westward moving West Greenland waters (Smith et al., 1937). In Hudson Strait, strong tides mix this current with low salinity waters flowing out from Hudson Bay and deep waters within the Strait. The resultant mixture is transported onto the Labrador Shelf forming the inshore branch of the Labrador Current (Kollmeyer et al., 1967). The westward extension of the West Greenland Current reaches the continental slope of Labrador where it forms the offshore branch of the Labrador Current. This offshore branch constitutes approximately $80 \%$ of the total transport within the Labrador Current (Lazier and Wright, 1993). Upon reaching the Grand Banks, the inshore branch of the Labrador Current turns southward through Avalon Channel, then westward towards the Gulf of St. Lawrence. The offshore branch flows along the outer edge of the Grand Banks, some passing north of Flemish Cap, but the majority continuing southward along the eastern slope to the Tail of the Banks (Petrie and Anderson, 1983). Part of this water flows westward along the southern edge of the Grand Banks while the rest is mixed into the slope water region. Waters that enter the Gulf of St. Lawrence through Cabot Strait circulate in a cyclonic direction, augmented by transport from the Labrador Shelf through the Strait of Belle Isle and by freshwater from the St. Lawrence Estuary (Koutitonsky and Bugden, 1991). The bulk of the outflow from the Gulf exits on the south side of Cabot Strait and moves onto the Scotian Shelf. Part rounds the eastern tip of Cape Breton Island remaining on the inner half of the shelf to form the Nova Scotia Current (Sutcliffe et al., 1976). The remainder flows along the Laurentian Channel, some spreading out over the northeastern Scotian Shelf and some turning at the outer edge of Banquereau Bank to flow southwestward along the continental slope. Although the major component of the flow over the Scotian Shelf is directed southwestward, anticyclonic and cyclonic eddies persist over several of the banks and basins, respectively. Leaving the Scotian Shelf, the flow continues into and around the Gulf of Maine, with some temporarily diverted into the Bay of Fundy (Bigelow, 1927). Upon reaching Cape Cod the current again splits, part flowing south towards the Middle Atlantic Bight and part northeastward where it concentrates along the northern flank of Georges Bank. The latter also splits, one branch moving north to complete the Gulf of Maine gyre and the other flowing around Georges Bank to form an anticyclonic gyre. Once onto the Middle Atlantic Bight, the water continues its southwestward journey towards Cape Hatteras.

The dominant feature offshore of the continental shelf between the Grand Banks and Cape Hatteras is the Gulf Stream (Fig. 2). Near the Tail of the Bank, the Gulf Stream splits with one branch continuing east to southeast and the other branch northward through the Newfoundland Basin, around Flemish Cap and towards the Labrador Sea. The latter branch, known as the North Atlantic Current, then makes a large loop finally heading eastward towards the Irminger Sea. This current eventually contributes to the Irminger Current.

South of Newfoundland, the area between the continental shelf waters and the Gulf Stream is occupied by "slope waters". Exchange between shelf and slope waters occurs regularly but is enhanced in the presence of Gulf Stream rings. Rings form from Gulf Stream meanders and at times entrain large volumes of shelf water offshore while pushing equal volumes of slope waters onto the shelf (Smith, 1978)

The mean circulation provides an oceanic link between shelf regions within the Northwest Atlantic (Fig. 2). The observed variability in oceanographic conditions in the shelf waters, therefore, depends not only on local atmospheric and offshore forcing but also upon upstream conditions which are advected downstream by the residual circulation. It is important to recognize, however, that the strength and direction of the flow can or may change seasonally. Together with higher frequency current variability, this can result in the flow at any particular time differing substantially from the long-term mean flows shown in Fig. 2.

\section{Data and Methods}

The climatological data used in the present study are derived from several sources. Monthly mean air temperatures were obtained from 14 coastal sites whose location and length of record are listed in Table 1. Gridded monthly mean sea level pressures over the North Atlantic Ocean (1950-95) were obtained from Die Grosswetterlagan Europas published by the German Meteorological Service. Winter (December, January, February averaged) sea level pressures (1895-1995) from Ponta Delgada in the Azores and Akureyi in Iceland used to calculate the North Atlantic Oscillation (NAO) Index were taken from the World Weather Records, published by the Smithsonian Institute, and updated in recent years from the Monthly Climatic Data for the World, published by the National Oceanic and Atmospheric Administration (NOAA). Monthly geostrophic wind stress estimates (1946-91) derived from $6 \mathrm{hr}$ sea level pressures were available at 25 sites in the NW Atlantic from the Labrador Sea to Georges Bank (Drinkwater and Pettipas, 1993). Monthly sea ice coverage off Newfoundland (1963-95) expressed as the ice area between $45-55^{\circ} \mathrm{N}$ were kindly provided by 
TABLE 1. The location and length of record of the air temperature sites used in the study.

\begin{tabular}{lccc}
\hline \hline Location & Latitude & Longitude & Years \\
\hline Angmagssalik, East Greenland & 65.60 & 37.63 & $1895-1995$ \\
Upernavik, West Greenland & 72.78 & 56.17 & $1880-1995$ \\
Godthaab (Nuuk), West Greenland & 64.25 & 51.58 & $1866-1995$ \\
Iqaluit, Baffin Is. & 63.75 & 68.55 & $1946-1995$ \\
Kuujjuaq, Quebec & 58.10 & 68.42 & $1947-1995$ \\
Cartwright, Labrador & 53.70 & 57.03 & $1934-1995$ \\
St. John's, Newfoundland & 47.62 & 52.75 & $1874-1995$ \\
Charlottetown, P.E.I. & 46.25 & 63.13 & $1872-1992$ \\
Sable Island, N.S. & 43.93 & 60.02 & $1898-1995$ \\
Sydney, N.S. & 46.17 & 60.50 & $1870-1995$ \\
Shearwater, N.S. & 44.63 & 63.50 & $1871-1995$ \\
Yarmouth, N.S. & 43.83 & 66.08 & $1871-1995$ \\
Boston, Mass. & 42.37 & 71.03 & $1871-1995$ \\
Cape Hatteras, N.C. & 35.27 & 75.55 & $1875-1995$ \\
\hline
\end{tabular}

I. Peterson (Bedford Institute of Oceanography, pers. comm.) and statistics on the duration of ice, i.e. the number of days ice was present, at sites off Newfoundland and in the Gulf of St. Lawrence were provided by Canada's Ice Central in Ottawa. The U.S. Coast Guard supplied the time series of icebergs drifting south of $48^{\circ} \mathrm{N}$ (1880-1995). Monthly mean freshwater discharge rates for the Ottawa, Saguenay, and St. Lawrence Rivers (191495) were obtained from the Canadian Department of the Environment. They also supplied runoff time series for the Saint John River which was estimated by combining measurements from the nearby sites of Pokiok (1921-67) and Mactaquac (1967-94) in New Brunswick.

Temperature and salinity data were obtained from an historical database maintained at the Bedford Institute of Oceanography (BIO). The data originated from Canada's national archive, the Marine Environmental Data Service in Ottawa, but have undergone additional quality control and editing procedures. Time series of hydrographic properties within designated areas were developed from the database. For example, within an area surrounding Fyllas Bank off West Greenland (see Fig. 1 for location), each temperature and salinity profile with a bottom depth of $<200 \mathrm{~m}$ was linearly interpolated to standard depths. All profiles within the Fyllas Bank area were then averaged by month to obtain a single representative monthly mean. A similar procedure was used to obtain monthly means for subareas within the Gulf of St. Lawrence, the Scotian Shelf and the Gulf of Maine. The majority of the data in the database are from oceanographic surveys and ships-of-opportunity, hence the time series in most areas are discontinuous with, at times, several months of missing data within any given year. Additional temperature and salinity data were obtained at regularly monitored sites, i.e. Station 27 off St. John's, Newfoundland (since the late 1940s) and Prince 5, at the mouth of the Bay of Fundy (since the 1920s). These were supplied by S. Narayanan (Northwest Atlantic Fisheries Center, St. John's, Newfoundland) and F. Page (St. Andrews Biological Station, New Brunswick), respectively. The area of the cold intermediate layer (CIL) in summer along the Bonavista transect off Newfoundland (see Fig. 1 for location) was also provided by S. Narayanan.

The monthly mean data were averaged into seasonal, annual and decadal means. Variability is typically expressed in terms of anomalies, i.e. differences from long-term climatic means (196190, where possible). The thirty-year period coincides with that used by meteorologists and recommended by the World Meteorological Organization. In the case of discontinuous monthly data, the annual anomalies were estimated from the average of the available monthly anomalies for the particular year in question, regardless of the number.

\section{Atmospheric Conditions}

\section{Air Temperatures}

Decadal mean air temperature anomalies for the 1980s showed cold conditions over the Labrador Sea and Baffin Bay, in contrast to the warm conditions from Newfoundland to Cape Hatteras (Fig. 3). The coldest area was along West Greenland and the warmest at Cape Hatteras, near the southern NAFO boundary.

At Godthaab (also known as Nuuk), which is representative of the Labrador Sea region and has temperature records extending back 12 decades, 


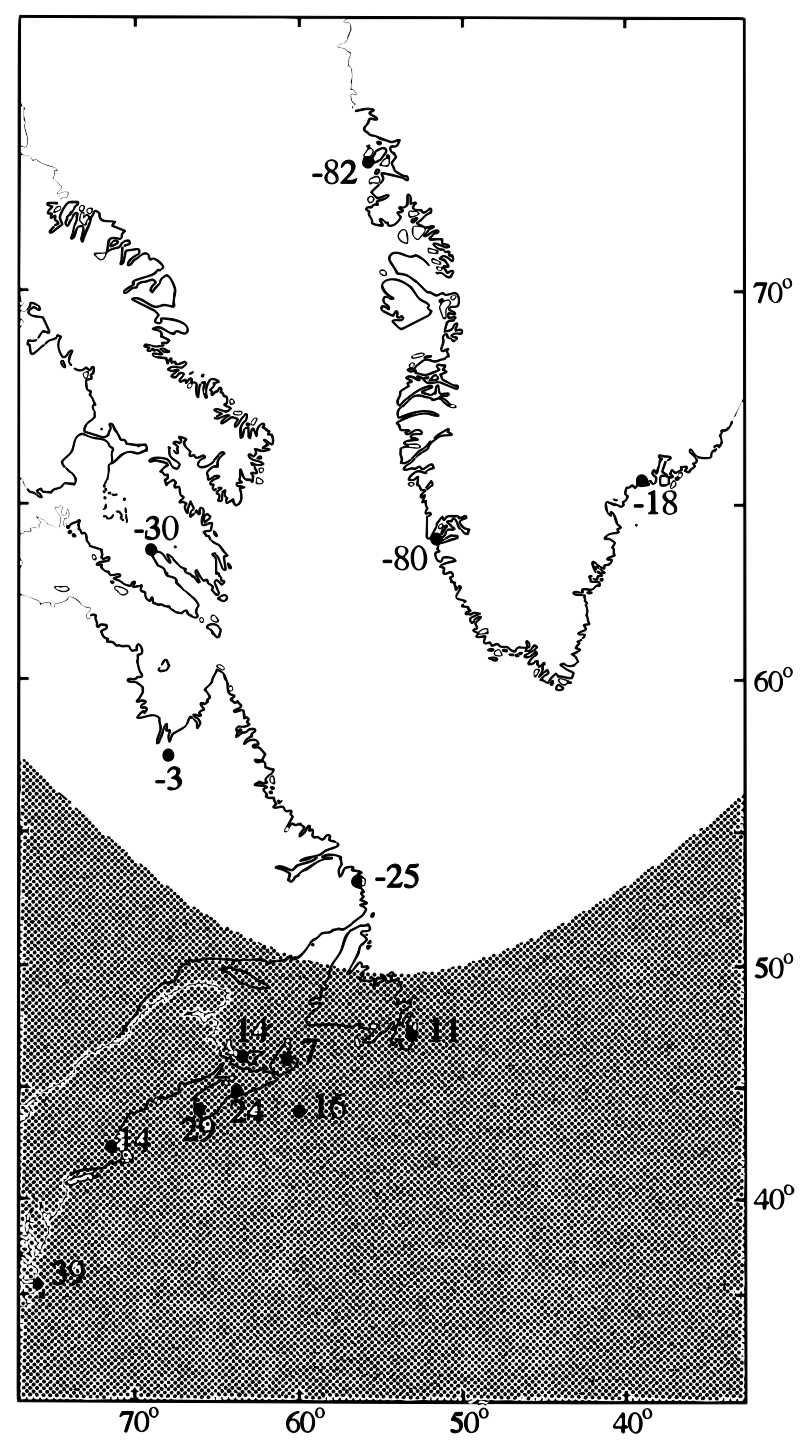

Fig. 3. The 1980s decadal mean air temperature anomaly in hundredths of a degree relative to 1961-90. The shading indicates positive anomalies.

it was the second coldest decade on record with only the 1880s being colder (Fig. 4). Decadal mean temperatures at Godthaab rose steadily from the 1880s to above normal in the 1920s, remained high through to the 1960s, and have declined steadily since then. At Cape Hatteras, decadal anomalies are smaller than at Godthaab but show a similar trend from the late 1880s to the 1950s (Fig. 5). Since then, however, the trends have diverged with anomalies at Cape Hatteras dropping to well-below normal in the 1960s followed by a gradual rise. In between these northern and southern regions, from Newfoundland to the Gulf of Maine, coastal air temperature sites show slightly positive decadal anomalies in the 1980s but no distinct trend since
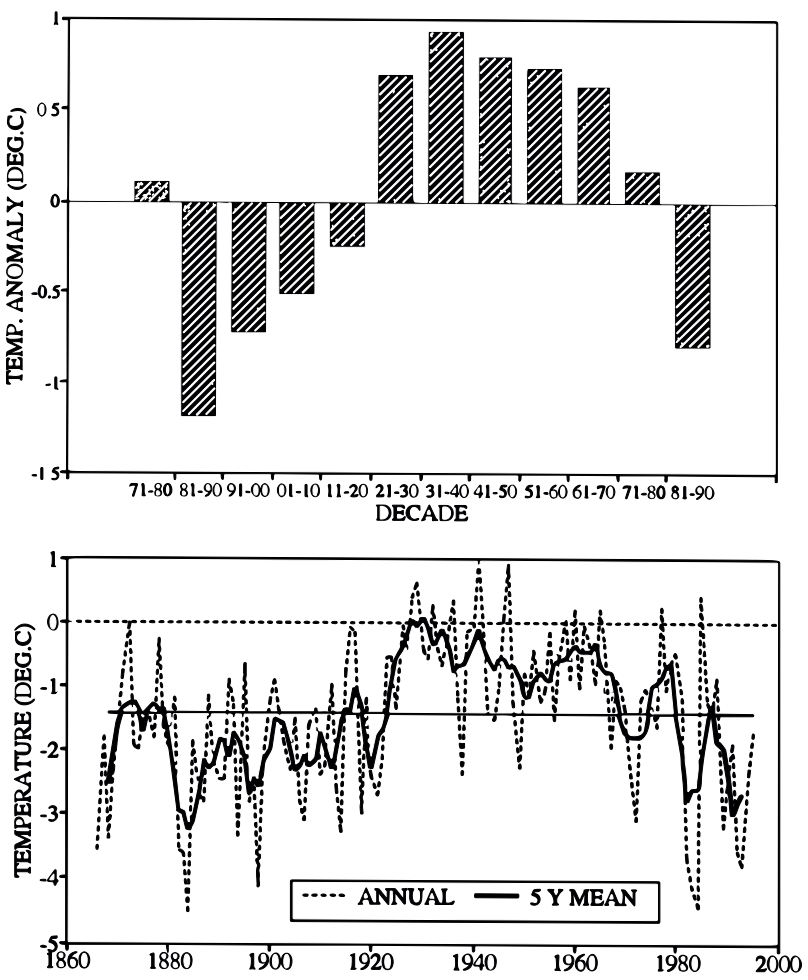

Fig. 4. Godthaab air temperatures. Decadal anomalies (top) and annual temperatures (bottom). The solid horizontal line denotes the long-term (196190) mean.

the 1960s (Fig. 6). In this region, the warmest decade was the 1950s.

Within decade variability is high, especially at Godthaab and Cape Hatteras. At Godthaab, the decade began with very cold temperatures, followed by a rise to a peak in the mid-1980s before falling again to very cold temperatures by the end of the decade (Fig. 4). These very cold waters persisted into the 1990s. This appears to be part of a near decadal temperature oscillation that became established after 1960 and is in addition to the steady decline. Temperature minima were reached in the early 1970s, 1980s and 1990s. At Cape Hatteras, it was relatively cold at the beginning of the 1980s and generally rose through the remainder of the decade with brief maxima in the mid and late1980s (Fig. 5).

At all sites, the season exhibiting the largest temperature anomaly is typically winter and it generally defines the magnitude and sign of the annual anomaly. This was the case for the 1980s and first half of the 1990s, although all seasons show similar trends, i.e. they were colder-thannormal in the north and warmer-than-normal in the south. 

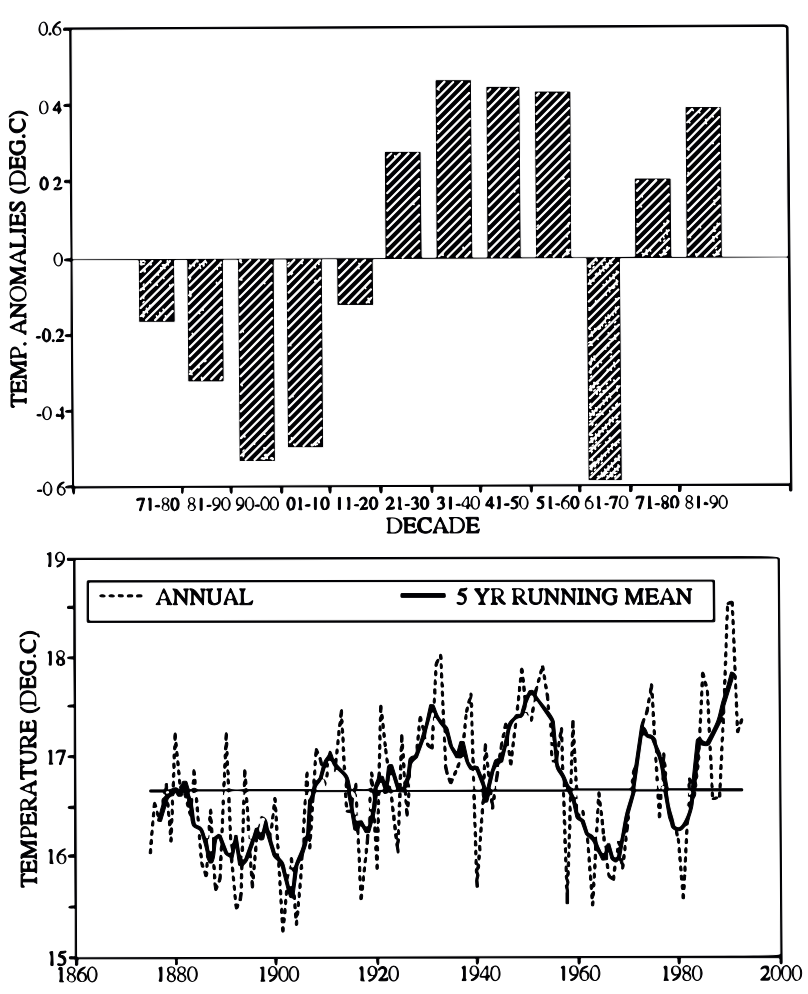

Fig. 5. Cape Hatteras air temperatures. Decadal anomalies (top) and annual temperatures (bottom). The solid horizontal line denotes the long-term (1961-90) mean.

\section{Air Pressures}

Air temperature trends are often closely related to the large-scale atmospheric circulation patterns. In the North Atlantic, the sea level pressure patterns are dominated by the Icelandic (subpolar) Low and the Bermuda-Azores (subtropic) High (Fig. 7). The strengths of the Low and High vary seasonally from a winter maximum to a summer minimum. Year-toyear changes in winds are associated with interannual variations in the intensity of these pressure systems, e.g. a deeper low and higher high result in stronger westerly winds over the North Atlantic and stronger northwesterly winds over the Labrador Sea. Seasonally, winter (December, January and February) pressures exhibited the largest interannual and decadal variability.

The winter sea level pressure pattern in the 1980s is shown in Fig. 8 together with the contrasting pattern observed during the 1960s. In the 1960s, the Icelandic Low and Bermuda-Azores High were relatively weak (positive and negative anomalies, respectively). The associated anomalous winds (see below) were from the south to southeast over the Labrador Sea and Baffin Bay producing relatively mild conditions. The anomalous winds
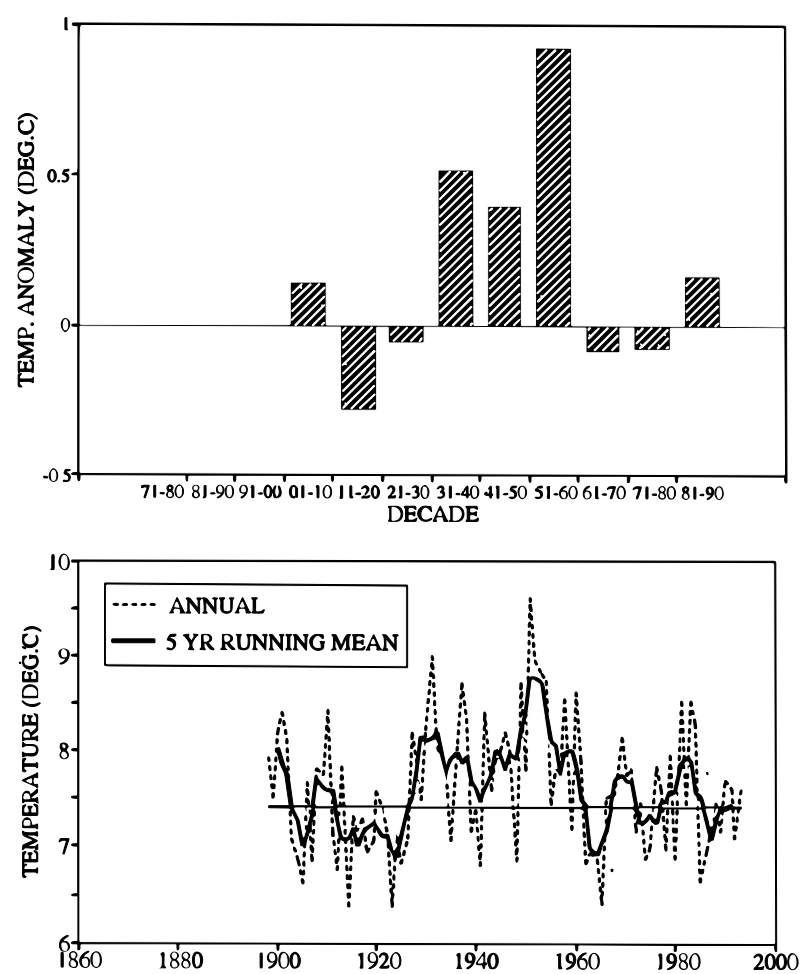

Fig. 6. Sable Island air temperatures. Decadal anomalies (top) and annual temperatures (bottom). The solid horizontal line denotes the long-term (1961-90) mean.

over southeastern Canada were from the northeast. Over the northeastern seaboard of the U.S. they were from the north to northwest and contributed to the colder-than-normal conditions. In contrast, both pressure systems in the 1980s intensified, causing stronger northerly and northwesterly winds over the Labrador Sea which brought Arctic air further southward thereby contributing to the cold air temperatures. The strengthening of the BermudaAzores High resulted in stronger southerly to southeasterly winds and hence warmer-than-normal air along the coast between Cape Hatteras to the Gulf of Maine.

The NAO index, defined as the winter sea level pressure at the Azores minus that at Iceland (Rogers, 1984) provides one measure of the strength of the large-scale atmospheric circulation (Lamb and Peppler, 1987). A high positive index is associated with an intensification of the atmospheric circulation including the northwesterly winds over the Labrador Sea. The cold air temperatures in the Labrador Sea in the 1980s correspond to a time of high NAO index whereas during the warm 1960s, the index was at a minimum (Fig. 9). The NAO index continues to remain high during the 1990s. Whereas 


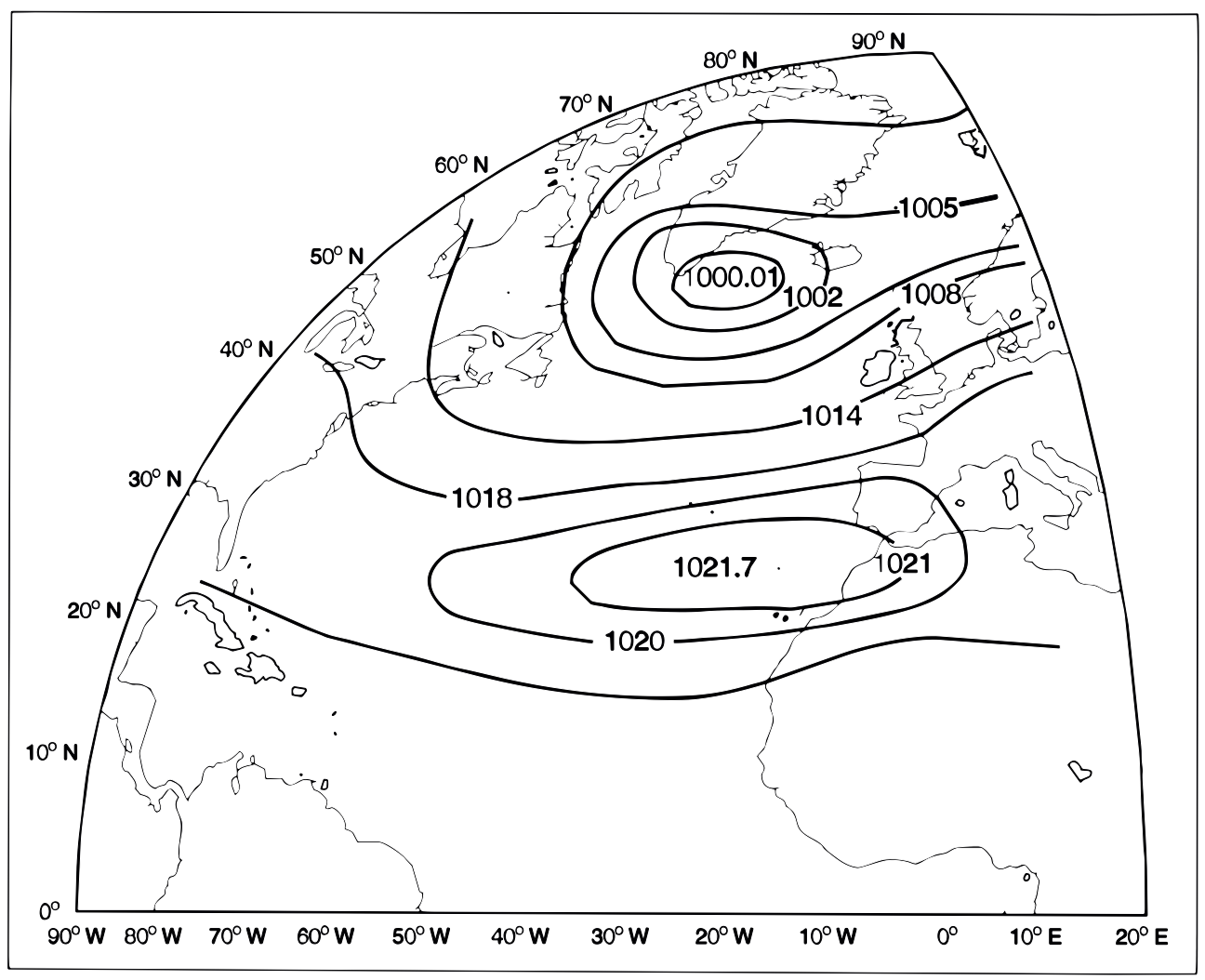

Fig. 7. The 1961-90 mean sea level pressure field over the North Atlantic Ocean during the winter (in $\mathrm{mb}$ ). The pattern is dominated by the Icelandic Low and the Bermuda-Azores High.

in the last three decades the inverse relationship of NAO to annual air temperature trends over the Labrador Sea has been reasonable strong, the NAO index does not correspond as closely with the annual air temperature trends at Godthaab in the first half of this century. This is due, in part, to differences in the importance of the winter temperatures in determining the annual mean. For example, the warming in the 1920s at Godthaab was dominated by warm springs (March, April and May) and summers (June, July and August) while in recent years the winters have dominated the annual anomaly. The index is most strongly correlated with winter air temperatures with correlations ( $r$ ) falling off through the spring and by summer are uncorrelated. The NAO index accounts for approximately $50 \%$ of the variance in the winter air temperatures within the Labrador Sea area (e.g. $r$ $=-0.72$ at Godthaab, $r=-0.77$ at Iqaluit, and $r=$ -0.68 at Cartwright) but falls to $r=-0.35$ at St. John's. The NAO index was uncorrelated with air temperatures at Sable Island and other stations in southern Canada and in the Gulf of Maine $(r<0.1)$ but further south correlations increased in magnitude and were positive, e.g. $r=0.44$ at Cape Hatteras.

\section{Winds}

Seasonal means of the geostrophic wind stresses were maximum in winter when winds are from the northwest to west and generally minimum in summer when from the southwest (Fig. 10). Yearto-year variability is also maximum during the winter season and generally is highest in the northern regions. In the Labrador Sea, the warm winters of the 1950s and 1960s coincided with anomalous winds from the southeast (Fig. 11). (Note that during these decades the winter winds still were from the northwest but much less than normal.) In contrast, the 1980s, and to a lesser extent the 1970s, show enhanced northwest winds over the Labrador Sea. During the 1950s when winter air temperatures were highest over the Gulf of St. Lawrence and Scotian Shelf, the westerly winds were much weaker than normal, i.e the anomalous winds were easterly.

The strength of the wind stress amplitude increased over the last 3 decades through most of Northwest Atlantic (Fig. 12). This, in part, may explain the increase in the frequency of large wave heights observed in the region during the 1970s and into the 1980s by Drinkwater and Trites (1989). The largest increase in wind stress has occurred in the 


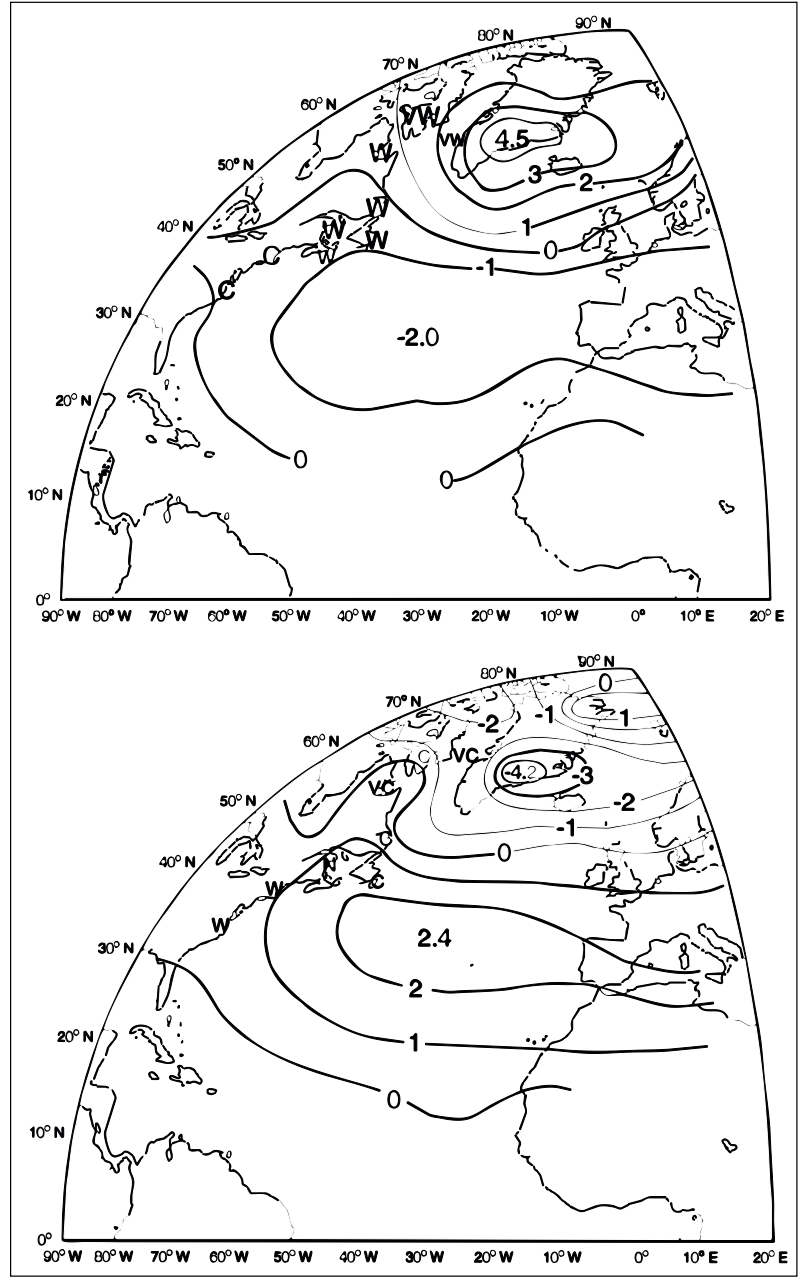

Fig. 8. Winter sea level pressure anomaly patterns (in $\mathrm{mb}$ ) during the 1960s (top) and 1980s (bottom). The decadal mean air temperatures at designated sites in the NW Atlantic are labelled as very warm (VW), warm (W), near normal (N), cold (C) or very cold (VC).

Labrador Sea where it doubled from the 1960s to the 1980s with the maximum change in winter. The stronger winds will have increased sensible and latent heat fluxes, thereby producing strong winter cooling of shelf waters and promoted deep convection in the central Labrador Sea.

\section{Ice Conditions}

Sea ice occurs seasonally over much of the Northwest Atlantic (Fig. 13) with the period of ice coverage increasing northward. The presence and volume of ice depends upon the rates of local ice formation, melting and southward advection of ice. The relative importance of these three processes vary seasonally as well as geographically. Near the southern limit, advection is the primary source of
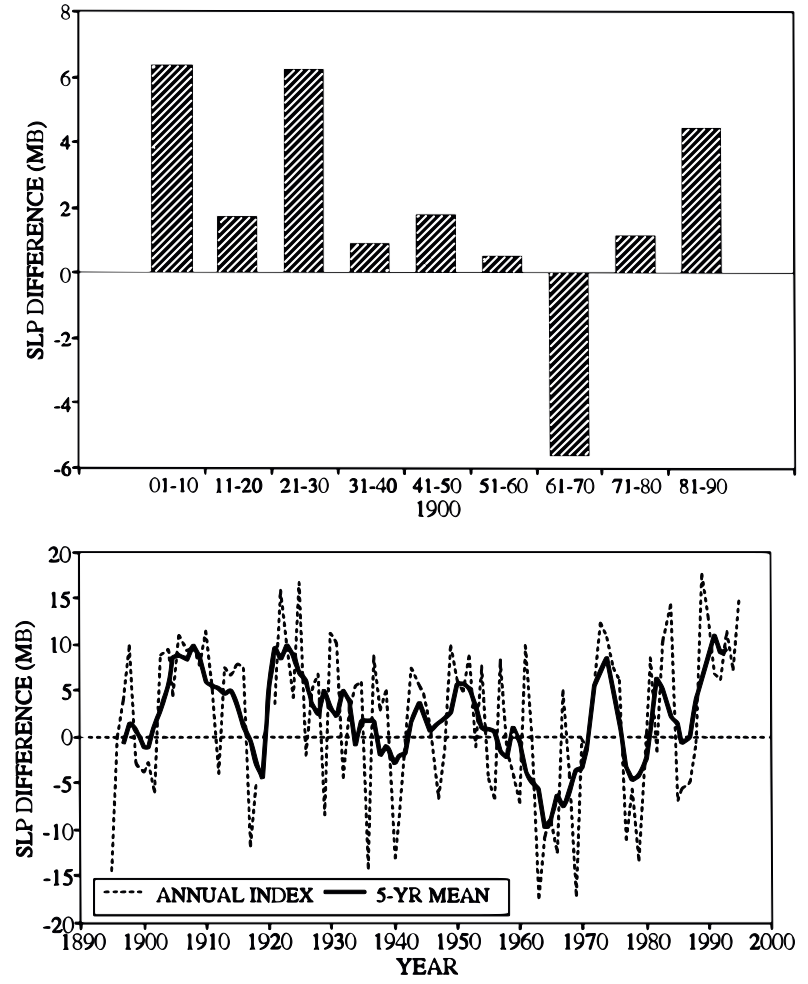

Fig. 9. The decadal (top) and annual (bottom) anomalies of the NAO Index.

ice. Interannual variability of the ice cover is large, especially in the Gulf of St. Lawrence and on the Grand Banks. In some years little to no ice was present in these regions whereas in other years ice extends to the southern Grand Banks and as far south on the Scotian Shelf as Halifax.

The decadal anomalies of sea ice extent off southern Labrador and Newfoundland (between 45$55^{\circ} \mathrm{N}$ ) during January to March (generally the period of southward advance of the ice) and April to June (northward retreat) indicate a gradual increase over the duration of the record with the greatest areal extent occurring during the 1980s (Fig. 14). (Note there were no data prior to 1963, hence the 1960s anomaly only includes 1963-70). This increase is more noticeable during ice advancement. The annual time series shows a near decadal oscillation in ice area with extensive coverage in the first half of each decade from the 1970s to the 1990s. The periods of extensive ice cover generally coincided with high NAO index, cold air temperatures and strong northwest winds. The association with the NAO was noted by Prinsenberg and Peterson (1994).

Additional ice information is provided from statistics on the duration of the ice season at 3 sites each off Newfoundland and in the Gulf of St. 

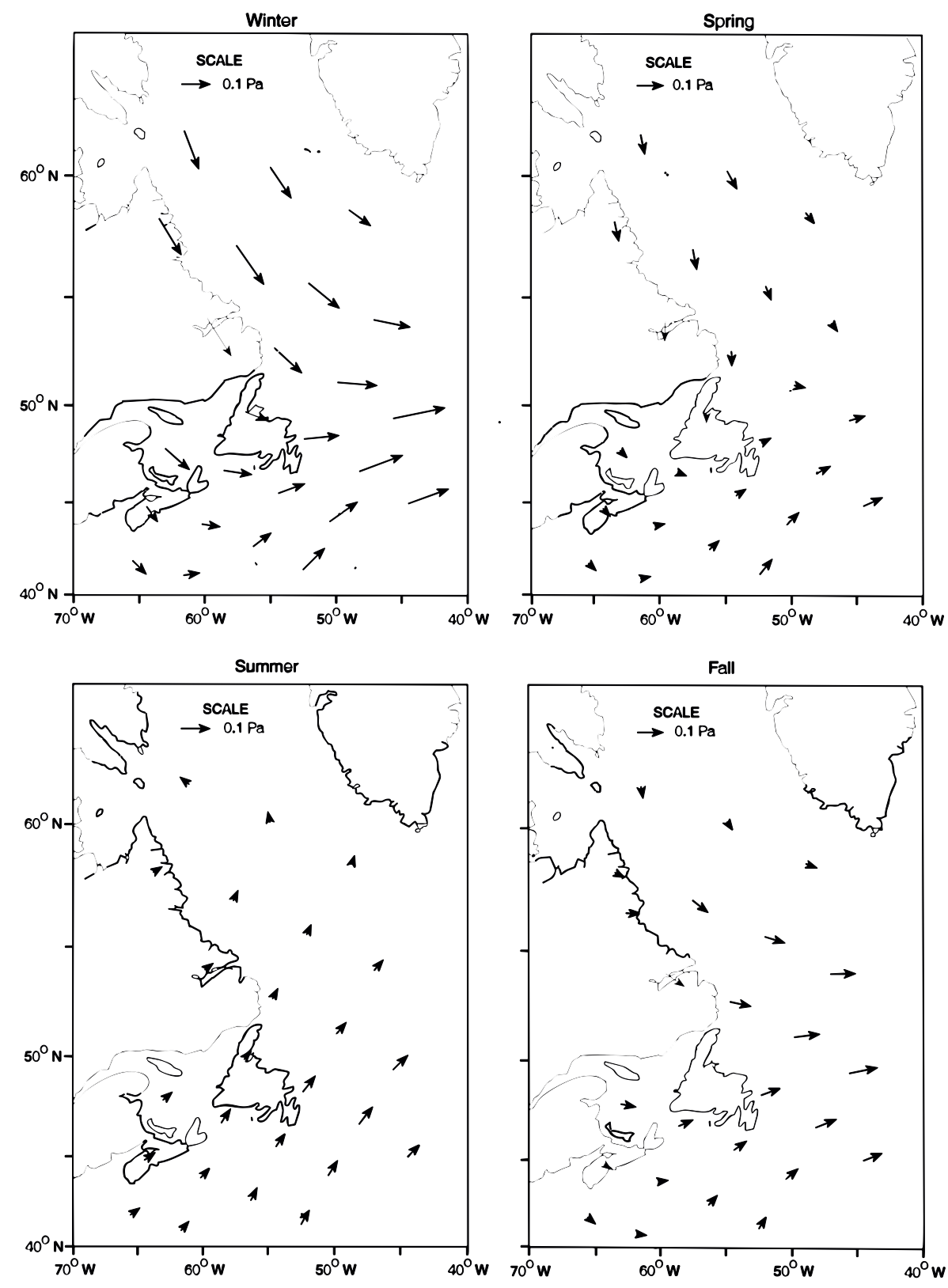

Fig. 10. The seasonal mean (1961-90) geostrophic wind stresses at 25 sites off the east coast of Canada.

Lawrence. Off Newfoundland, the ice duration typically increases inshore and northward but the interannual trends show similarities at all sites (Fig. 15). The correlations ( $r$ ) between ice duration at southern Labrador and northern Newfoundland is 0.71 and between the latter and the northern Grand Bank is 0.68 for the years 1969-95, although between Labrador and the Grand Banks it is only 0.38. Longer ice duration coincides with larger ice extent, thus, ice coverage was more extensive and stayed longer in the early 1970s, mid-1980s and in the early 1990s. In the Gulf of St. Lawrence the interannual trends in ice duration also show similarity between sites $(r=0.59-0.63,1969-95)$. There are two distinct minima, one in 1969-70 and the other in the early 1980s, with maxima in the early 1970s and mid to late 1980s. The ice season continues to be of relatively long duration during the 1990s. The pattern in the Gulf shows some similarity to that off Newfoundland and on the Grand Bank ( $r$ varies between 0.44-0.66) but is only weakly related to conditions off Labrador $(r<0.3)$. 

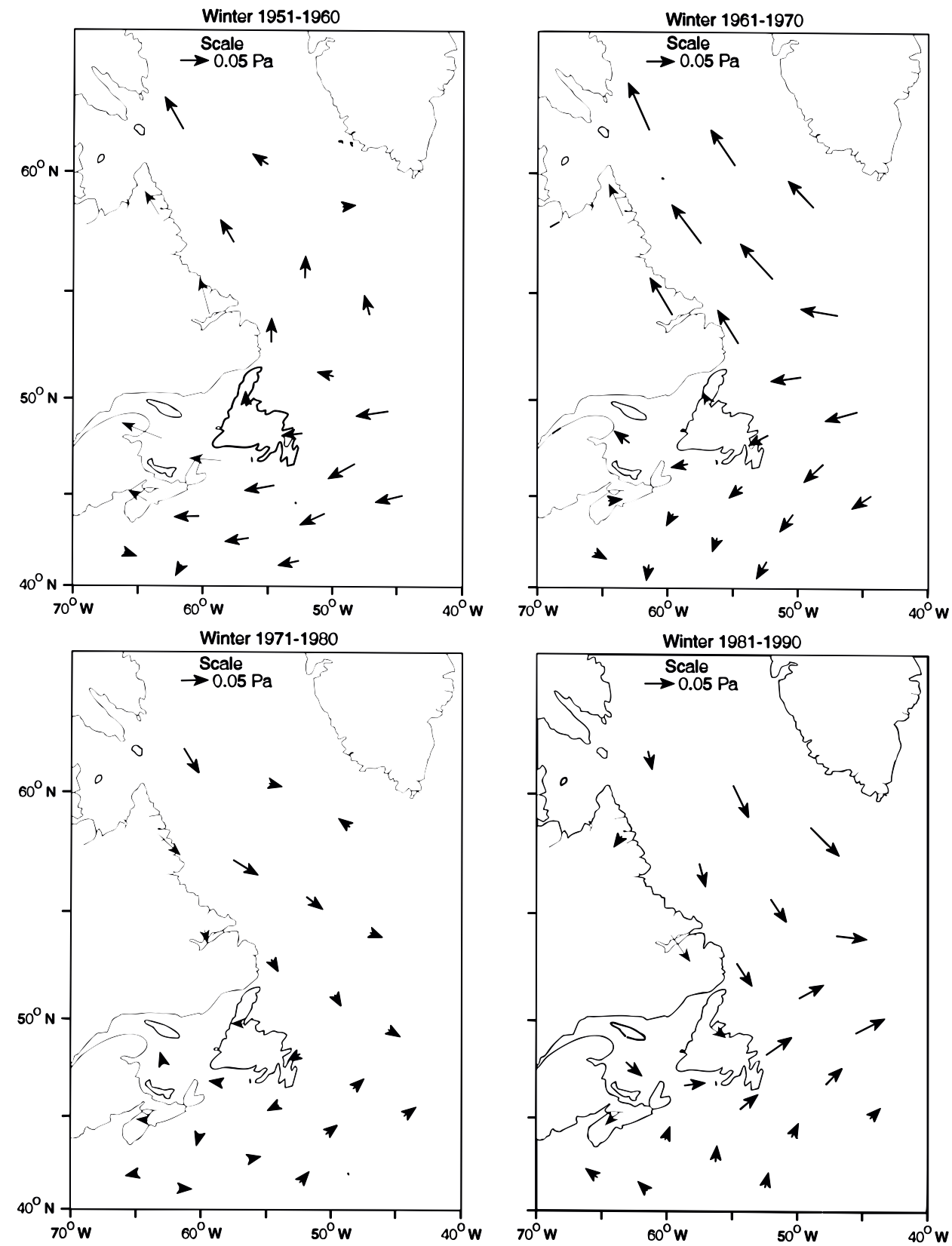

Fig. 11. The winter wind stress anomalies for the 1950s, 1960s, 1970s and 1980s.

Ice also appears in the northern regions in the form of icebergs. They originate from glaciers on West Greenland and northern Baffin Island, drift around Baffin Bay and eventually are carried by the residual currents southward, some reaching the Grand Banks (Anderson, 1971). The extent of the drift depends upon the current speed, air and sea temperatures, ice cover and winds (Marko et al., 1994). Stronger northwest winds tend to push the icebergs further south while the accompanying cold air temperatures delay melting and the heavy sea ice reduces wave activity which also decreases the melting rate. The large-scale atmospheric circulation influences the number of icebergs reaching the Grand Bank (Smith, 1931). The number of icebergs passing south of $48^{\circ} \mathrm{N}$ each month are monitored by the U.S. Coast Guard. The majority (on average over 90\%) appear between March and July. In the first half of this century, iceberg counts relied upon ship observations. After WWII directed flights were used to spot icebergs and since 1983 they have been detected on flights with SLAR (SideLooking Airborne Radar). SLAR is believed to spot more icebergs than the traditional observational 

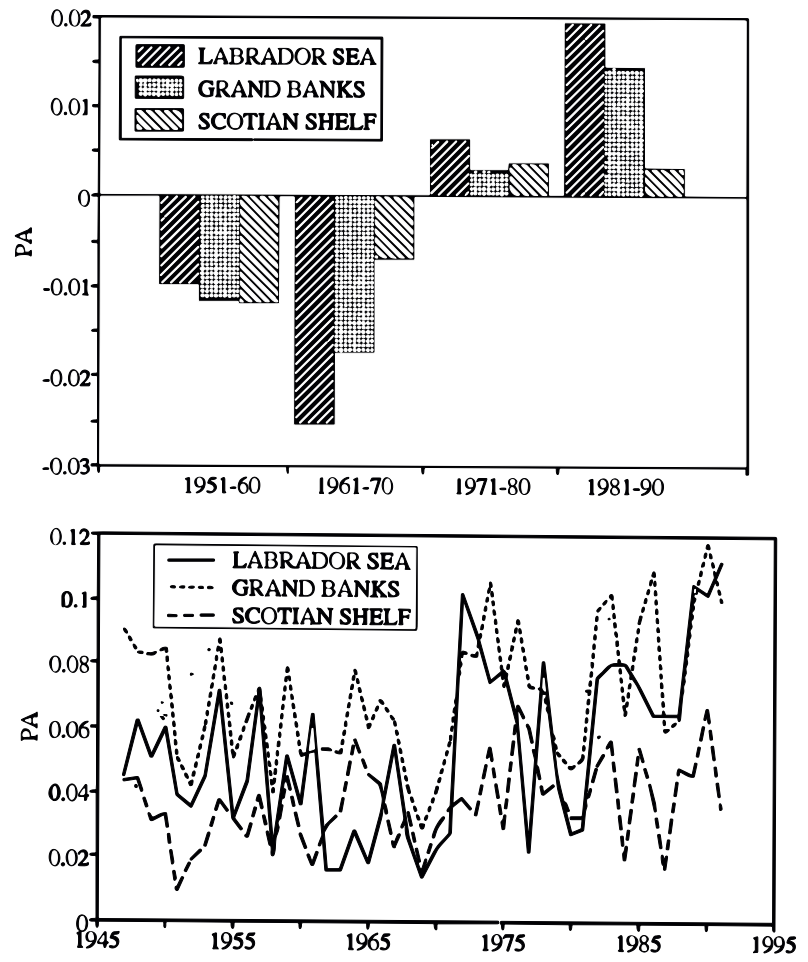

Fig. 12. The decadal (top) and annual (bottom) amplitudes of the wind stress anomalies over the Labrador Sea, the Grand Banks (including the northern Newfoundland Shelf) and the Scotian Shelf (including the Gulf of St. Lawrence).

methods and direct comparison between the iceberg index derived from the different methods can only be considered as relative. Further, during the first two years SLAR was used it is believed that there was a substantial overestimate of the number of bergs reported south of $48^{\circ} \mathrm{N}$ (I. Anderson, U.S. Coast Guard, Groton, Connecticut, pers. comm.). Recognizing these difficulties, the decadal and annual means of the iceberg index are shown in Fig. 16. High numbers of icebergs were observed in the 1990 s compared to the relatively low numbers of icebergs present in the 1950s and especially in the 1960s. During the 1980s low numbers of bergs were reported in the early years and in the later part of the decade. High numbers were observed in 1983 and 1984 and during the early 1990s. The highest iceberg counts generally occurred during periods of high NAO index, cold air temperatures, strong northwest winds and heavy ice.

\section{Hydrological Conditions}

\section{Gulf of St. Lawrence}

The freshwater discharge from the St. Lawrence River drainage basin exceeds that from all of the US rivers from Maine to southern Florida (Sutcliffe

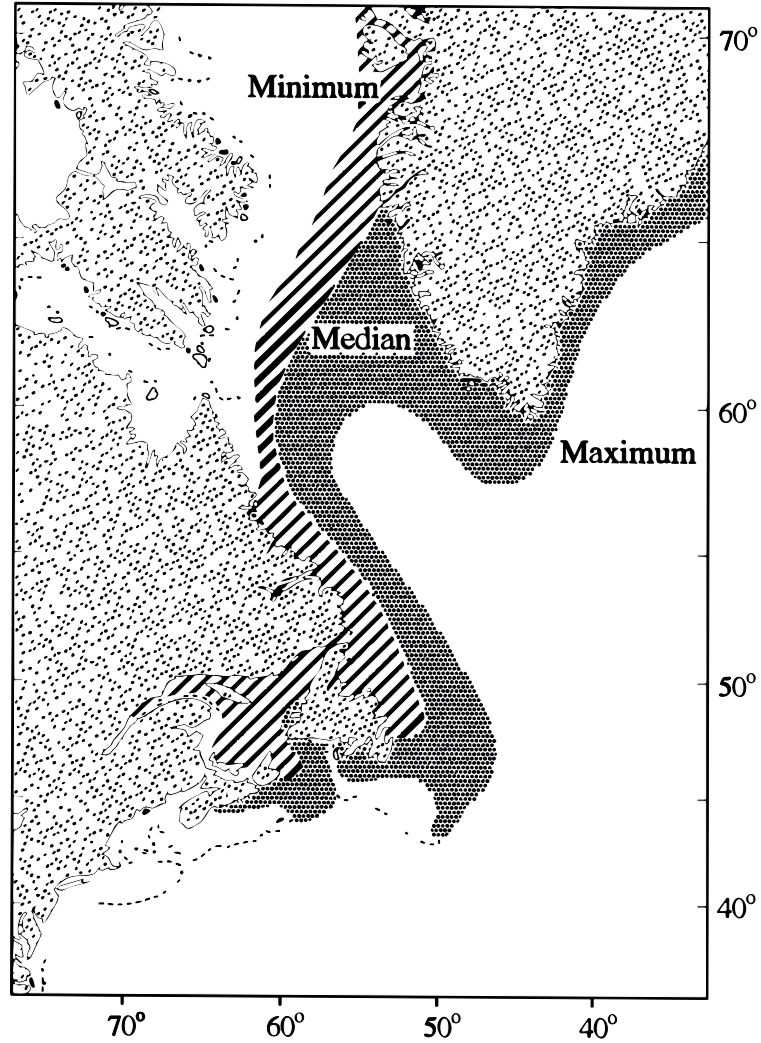

Fig. 13. The approximate location of the interannual minimum, median and maximum position of the edge of the sea ice (10\% concentration) during the peak ice season (based upon Coté (MS 1989) and Agnew (1993)).

et al., 1976). This discharge regulates the timing of the seasonal salinity minimum in the Gulf of St. Lawrence and on the Scotian Shelf and has been linked to interannual variability in hydrographic properties from the Gulf of St. Lawrence to the Middle Atlantic Bight (Sutcliffe et al., 1976; Manning, 1991). Decadal mean discharge rates for the combined runoff from the St. Lawrence, Ottawa and Saguenay Rivers (labelled RIVSUM after Sutcliffe et al., 1976) during the 1980s was the second highest decade on record (Fig. 17). The highest discharges were in the 1970s with relatively low discharge rates for the previous five decades. Within the 1980s, runoff was highest in the middle of the decade, then declined to rates observed in the late 1960s by the early 1990s.

\section{Gulf of Maine}

The largest and most important river discharging into the Gulf of Maine is the Saint John River. The decadal mean for the Saint John River in the 1980s is near its long-term average (Fig. 18). The highest discharge rates were observed in the 1970s, similar to RIVSUM, and the lowest on record 

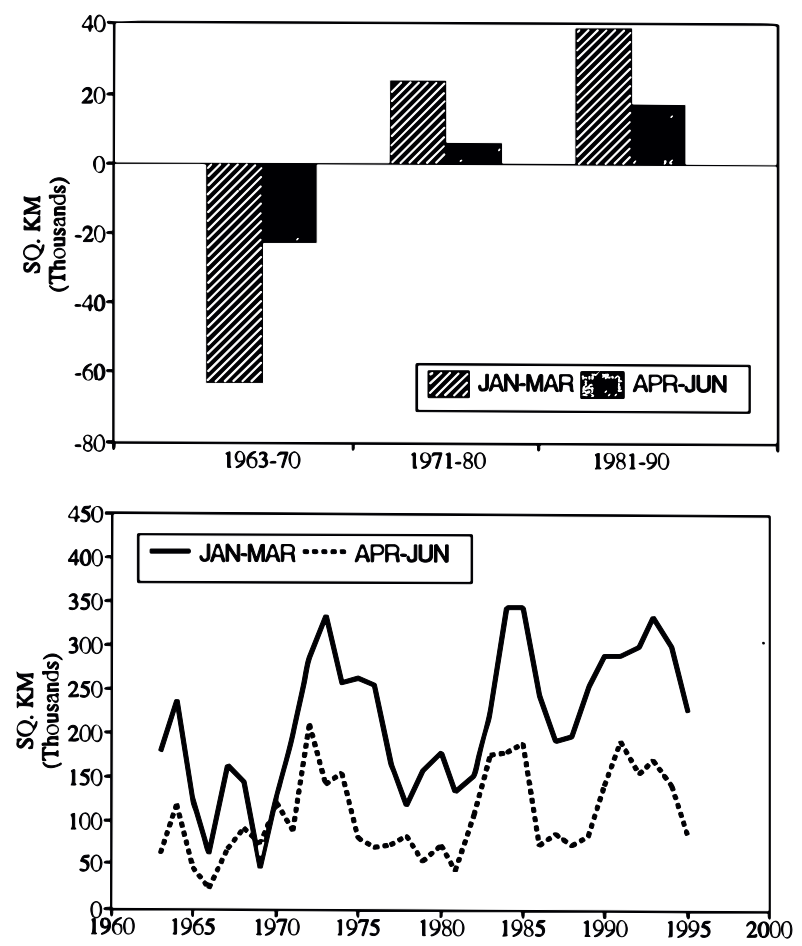

Fig. 14. The decadal (top) and annual (bottom) variability in the average ice extent during January to March (ice advance) and April to June (ice retreat)
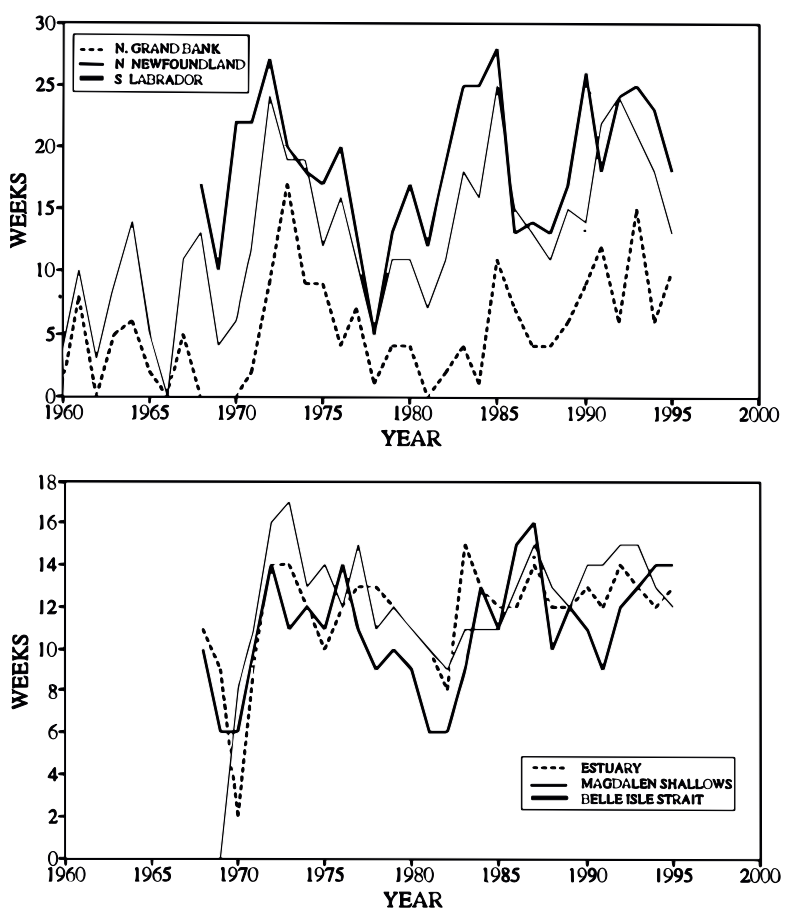

Fig. 15. The annual duration of sea ice at three locations off Newfoundland (top) and in the Gulf of St. Lawrence (bottom).
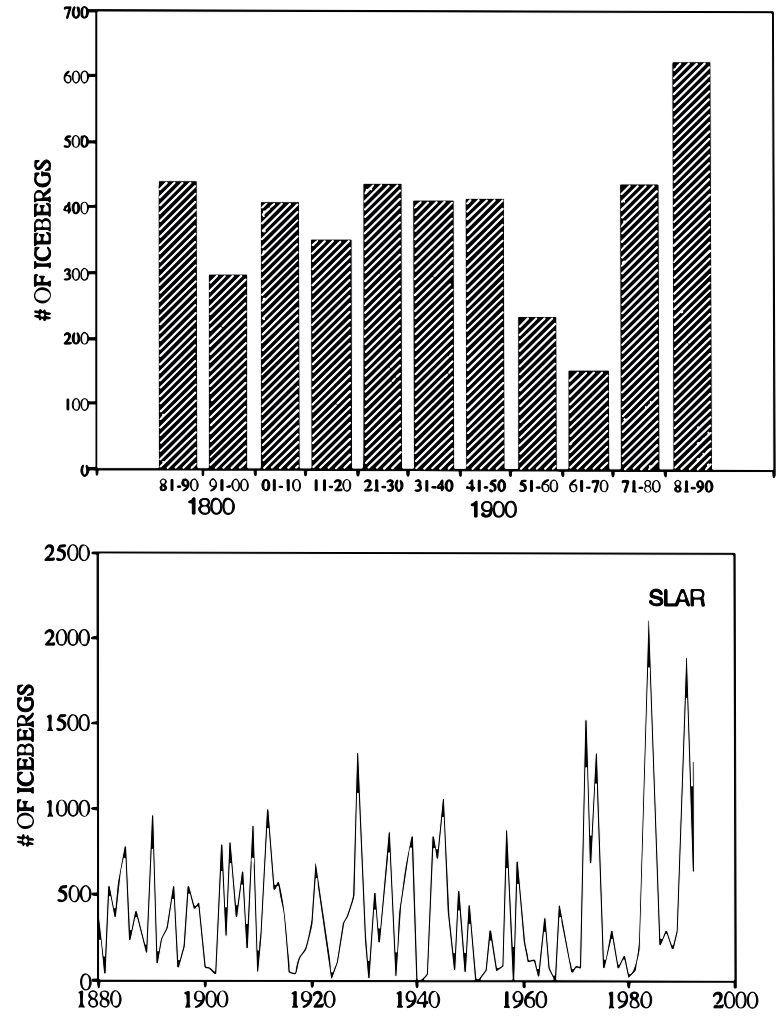

Fig. 16. The decadal (top) and annual (bottom) number of icebergs crossing south of $48^{\circ} \mathrm{N}$. Side-looking airborne radar (SLAR) has been used to detect icebergs since 1983.

in the 1960s. Within the 1980s, flows decreased from a high in the early years, to minima in the mid to late-1980s. Discharges rose dramatically at the end of the decade such that in the early 1990s they have been above normal.

\section{Oceanographic Conditions}

\section{West Greenland (NAFO Subarea 1)}

Decadal anomalies of ocean temperatures at Fyllas Bank during the 1980s were slightly below normal over the top $50 \mathrm{~m}$ of the water column and above normal at $100 \mathrm{~m}$ (Fig. 19). The magnitude of the anomalies were low $(<0.2)$, as they had been for the previous 2 decades. All were significantly lower than the temperatures during the 1950s. The decadal averaging masks an approximate $10 \mathrm{yr}$ oscillation with minima around 1970, 1980 and in the 1990s. Although the 1990s have experienced high variability, temperatures for the most part have continued below normal. Similar temperature trends have been reported in waters over other banks off West Greenland and along the continental slope (Buch and Stein, 1989; Stein, 1993). 

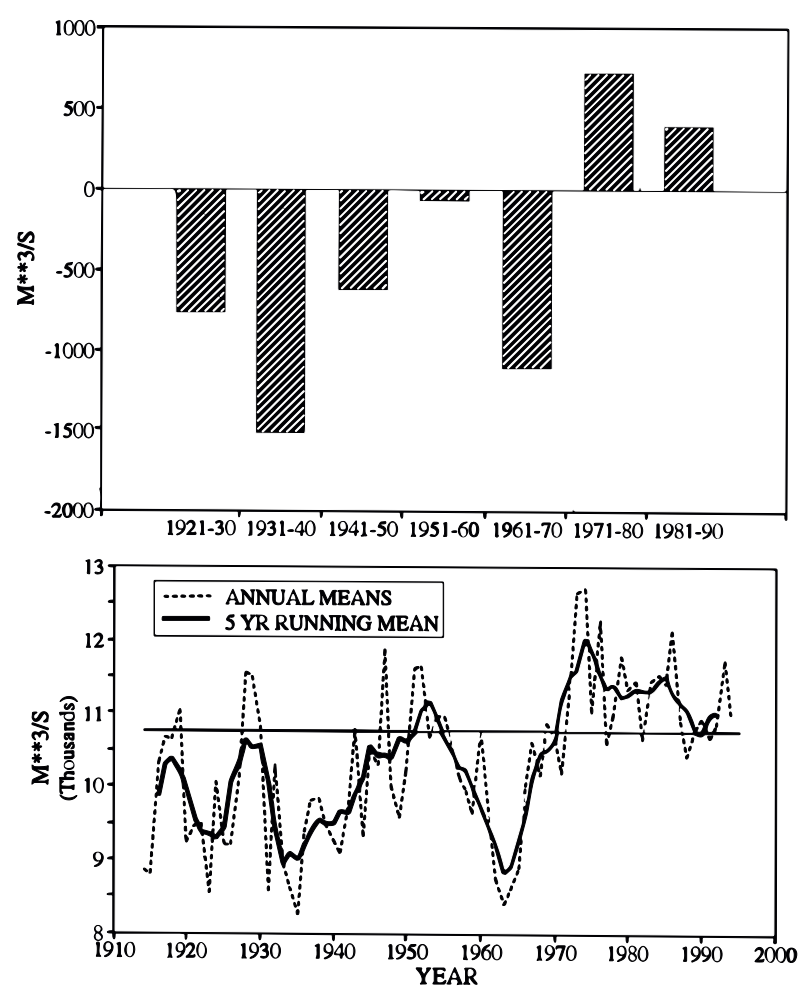

Fig. 17. The decadal (top) and annual (bottom) discharge from the combined St. Lawrence, Ottawa and Saguenay rivers (RIVSUM). The solid horizontal line denotes the 1961-90 mean.

Decadal salinity anomalies show the 1980s to be the most saline in the past 4 decades and have generally been rising since a minimum in the 1960s. An exception to this rise was a freshening in the early years of the 1980s, corresponding in time to the presence of cold waters (Fig. 19). Salt content rose again during the mid and late 1980s as temperatures warmed (Fig. 20). The low salinities in the late 1960s corresponded to the passage of the Great Salinity Anomaly (Dickson et al., 1988).

The near decadal oscillation in ocean temperature observed at Fyllas Bank matches closely that observed in the air temperature records at Godthaab, suggesting the possibility that the ocean temperatures are atmospheric forced. Buch and Stein (1989) suggested that cold air and strong northwest winds over the eastern Labrador Sea led to the anomalous cold oceanographic conditions off West Greenland in the early 1980s. However, Malmberg and Kristmannsson (1992) noted similar temperature, salinity variations in the waters on the northern Icelandic Shelf and linked them to a decrease in the percent Atlantic waters in the region. Since the Icelandic Shelf is adjacent to the source region of the Irminger Current it is
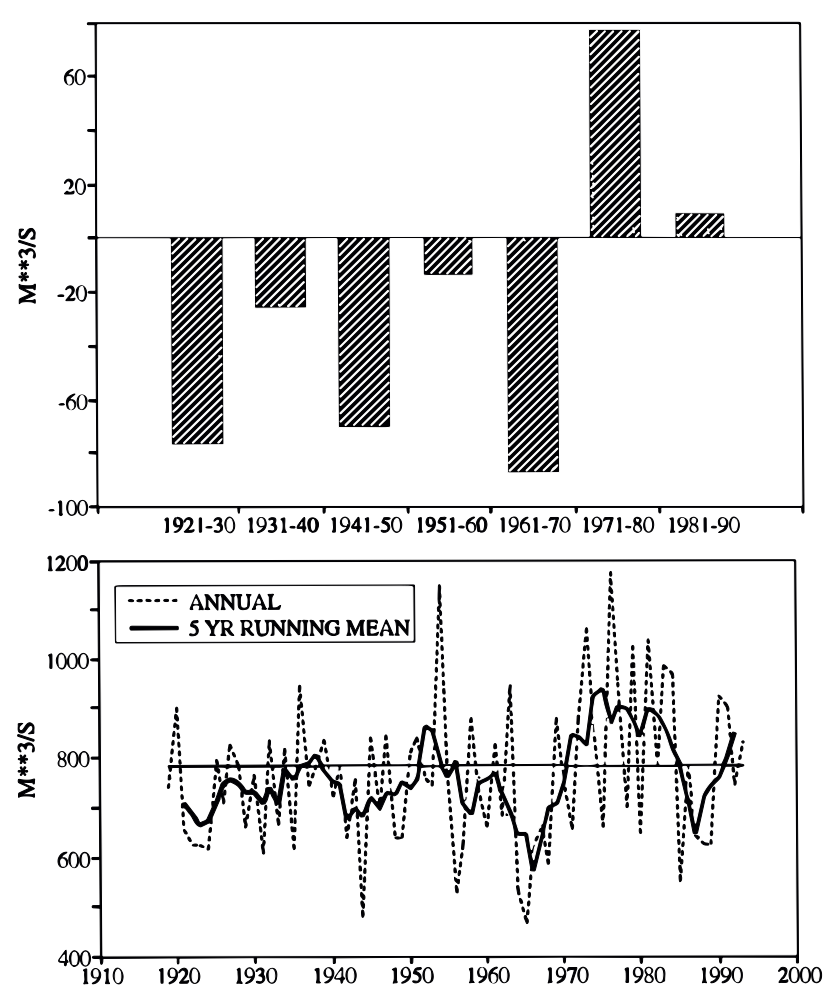

Fig. 18. The decadal (top) and annual (bottom) discharge from the Saint John River. The solid horizontal line denotes the 1961-90 mean.

conceivable that observed changes in the West Greenland Current may have been due, in part, to changes in the source waters. Indeed, the long-term temperature trend at Fyllas Bank does not reflect the long-term decline in air temperatures and increasing winds, as might be expected if atmospherically controlled. This argues that advection is an important source of hydrographic variability along West Greenland. Also changes in salinity cannot be accounted for by local processes as their are no local significant sources of freshwater or salt. The increasing salt content suggest either a change in the salinity of the upstream source waters or a difference in their proportions. Most likely both advection and atmospheric forcing are important in determining the observed changes on Fyllas Bank.

\section{Labrador Sea (Offshore Subareas 1 and 2)}

Lazier (1980) discussed interannual variability in the central Labrador Sea from data monitored at Ocean Weather Station (OWS) Bravo between 196474. Unfortunately, Bravo was removed in the mid1970 s so that observations of changes in the marine climate in the Labrador Sea now rely upon sporadic oceanographic surveys. Two studies have 

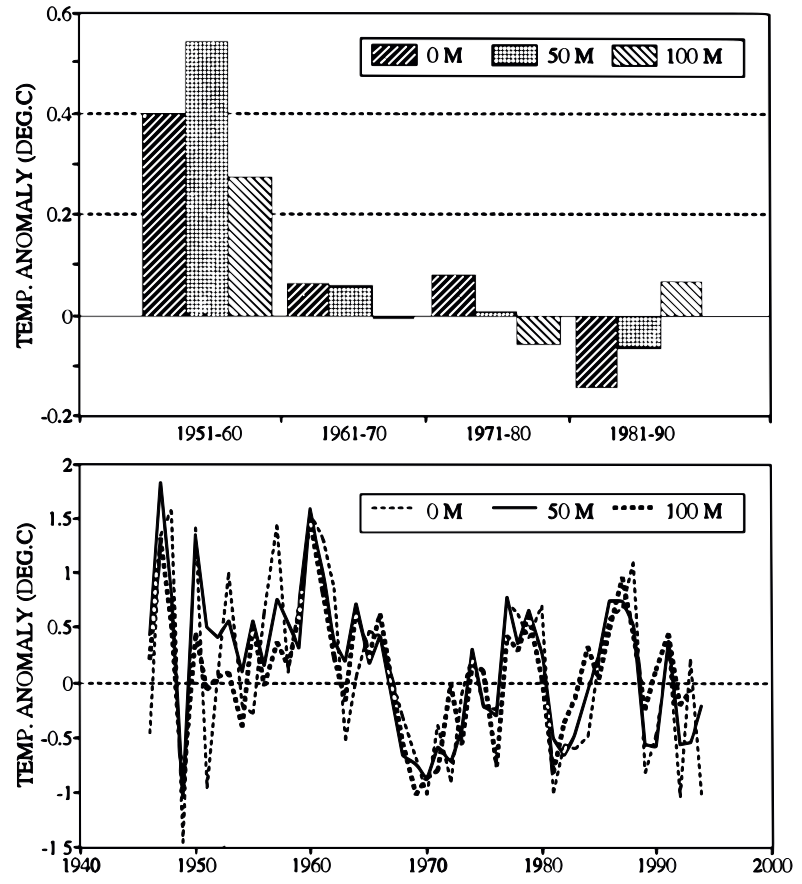

Fig. 19. The decadal (top) and annual (bottom) temperature anomalies at 0,50 and $100 \mathrm{~m}$ depth over Fyllas Bank.
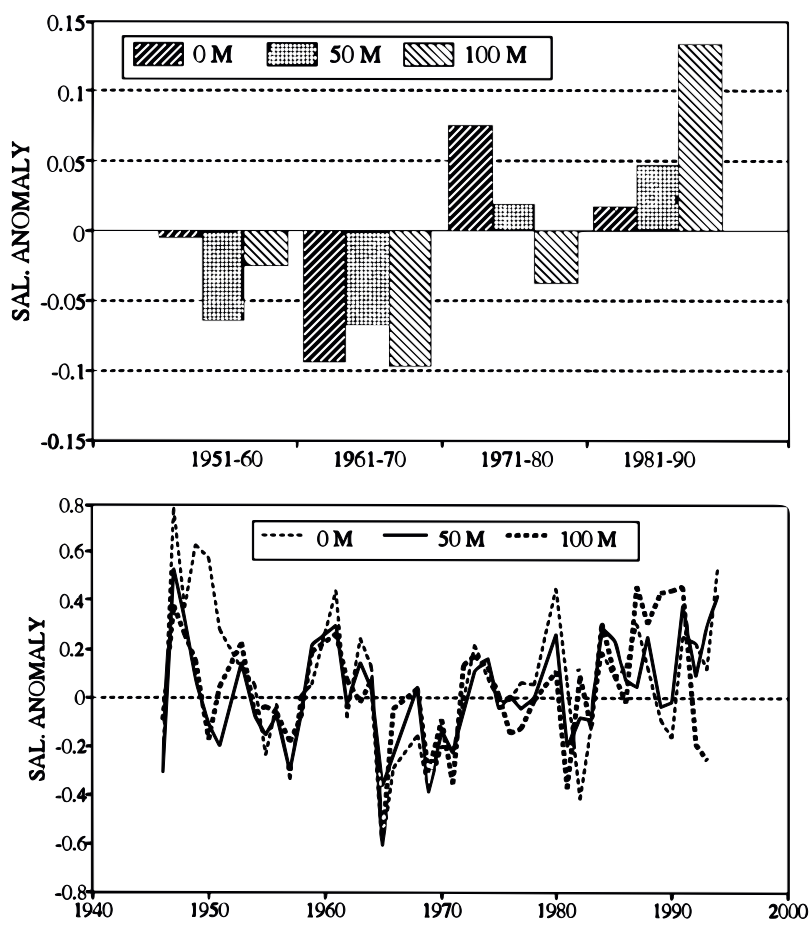

Fig. 20. The decadal (top) and annual (bottom) salinity anomalies at 0, 50 and $100 \mathrm{~m}$ depth over Fyllas Bank. investigated changes in the deep waters of the Labrador Sea during the 1980s. Lazier (1988) examined the deep (2 000-3 $000 \mathrm{~m}$ ) and bottom waters in the western Labrador Sea up to 1986 . He found relatively low temperatures and salinities in these water masses during the first half of the 1980s with a minor recover during 1986. The amplitude of the decline increased towards the bottom suggesting that the cause was probably changes in the temperature of the Denmark Strait Overflow water which flows into the Labrador Sea near bottom. Myers et al. (MS 1990) examined changes in salinity of the 500-2 $000 \mathrm{~m}$ depth layer in the vicinity of OWS Bravo from the 1930s on. Based on the scanty data for the 1980s, the salinities were relatively low in the 500-1 $000 \mathrm{~m}$ depth layer but relatively high between 1000-2 $000 \mathrm{~m}$. Examination of the temperature trends in the top $1000 \mathrm{~m}$ at the Bravo site based upon the data in the historical database made as part of the present study confirms the findings of Myers et al. (MS 1990) and also indicates that below $250 \mathrm{~m}$ temperatures were as cold as the minimum Lazier (1980) found between 1964-74. These very cold temperatures and low salinities appear to extend into the 1990s although few data are available. These conditions are believed to reflect deep water formation in the winter down to at least $1000 \mathrm{~m}$ due to the very cold air temperatures and strong NW winds. No decadal mean temperatures were calculated because of the paucity of data.

\section{Labrador Shelf/Grand Banks (Subareas 2 and 3)}

Interannual variability of the continental shelf waters from Labrador to the Grand Banks has been monitored by Newfoundland scientists since the late 1940s from occupation of standard oceanographic stations and sections. Most important of these has been Station 27 in the Avalon Channel just outside St. John's. It is situated within the inshore branch of the Labrador Current and is considered to reflect the general conditions in the shelf waters from Labrador to the Grand Banks (Petrie et al., 1992; Colbourne et al., 1994).

Decadal temperature anomalies at Station 27 peaked in the 1960s, then declined through to the 1980s which is the coldest decade since the record began in the late 1940s (Fig. 21). Within the 1980s, temperature anomalies at all depths were relatively warm at the beginning of the decade, having climbed steadily from the extremely low values of the early 1970s. This was followed by a decline to the mid-1980s with negative temperature anomalies matching those of the early 1970s. In the latter half of the decade, temperatures again rose, most rapidly in the very near surface layer but also in the 

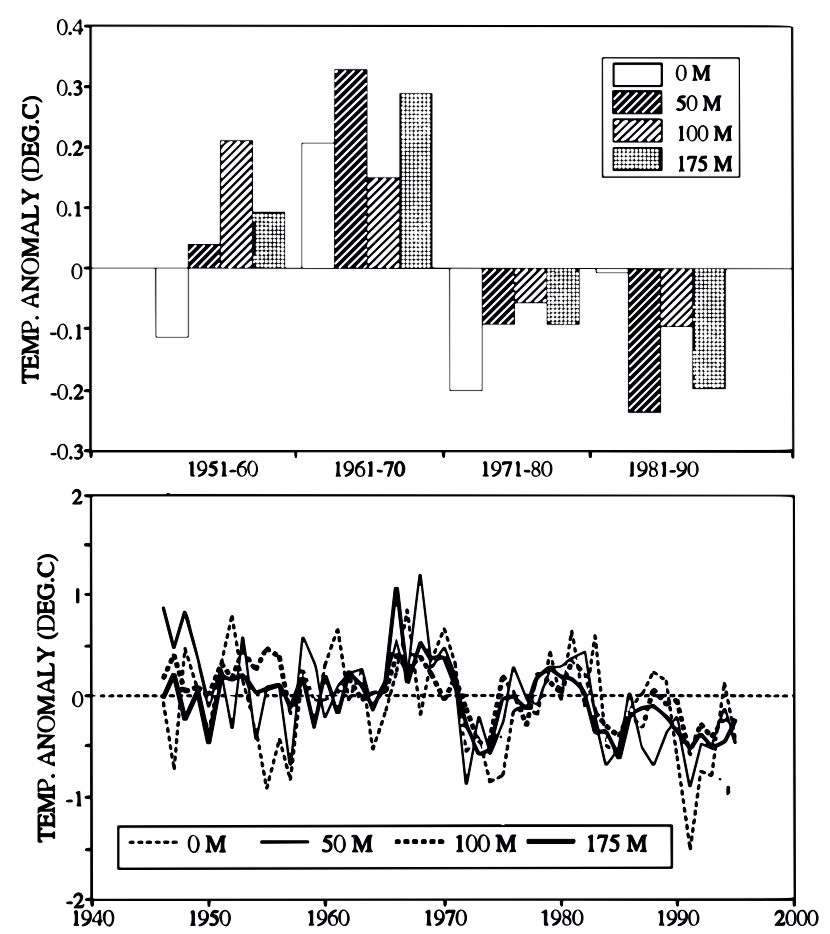

Fig. 21. The decadal (top) and annual (bottom) temperature anomalies at 0,50, 100 and $175 \mathrm{~m}$ at Station 27.

waters below $100 \mathrm{~m}$. At $50 \mathrm{~m}$, temperatures also began to rise but quickly fell. Temperature anomalies at all depths declined in the late 1980s such that by the early 1990s they were at or near their lowest value since the late 1940s. Anomalies remained below normal during the first half of the 1990s although they show signs of some moderation during the last couple of years.

The decadal salinity anomalies for the 1980s were above normal in the upper $100 \mathrm{~m}$ but below normal near bottom at $175 \mathrm{~m}$ (Fig. 22). The annual anomalies show a decline in the early to mid-1980s and an increase during the second half of the decade. Salinities reached maxima in the late 1980s and have declined to below normal at all depths during the 1990s. The extremely low surface salinities in the early 1970s, mid-1980s and early1990s are clearly evident (Fig. 22). Negative salinity anomalies occurred throughout the water column at these times but the subsurface salinity variations were of smaller amplitude. These three salinity minima occurred during years of cold temperatures, strong winds and heavy ice (Lazier, MS 1988; Colbourne et al., 1994).

Another index of the temperature conditions on the Labrador and Newfoundland Shelves is the areal extent of the CIL (Cold Intermediate Layer).
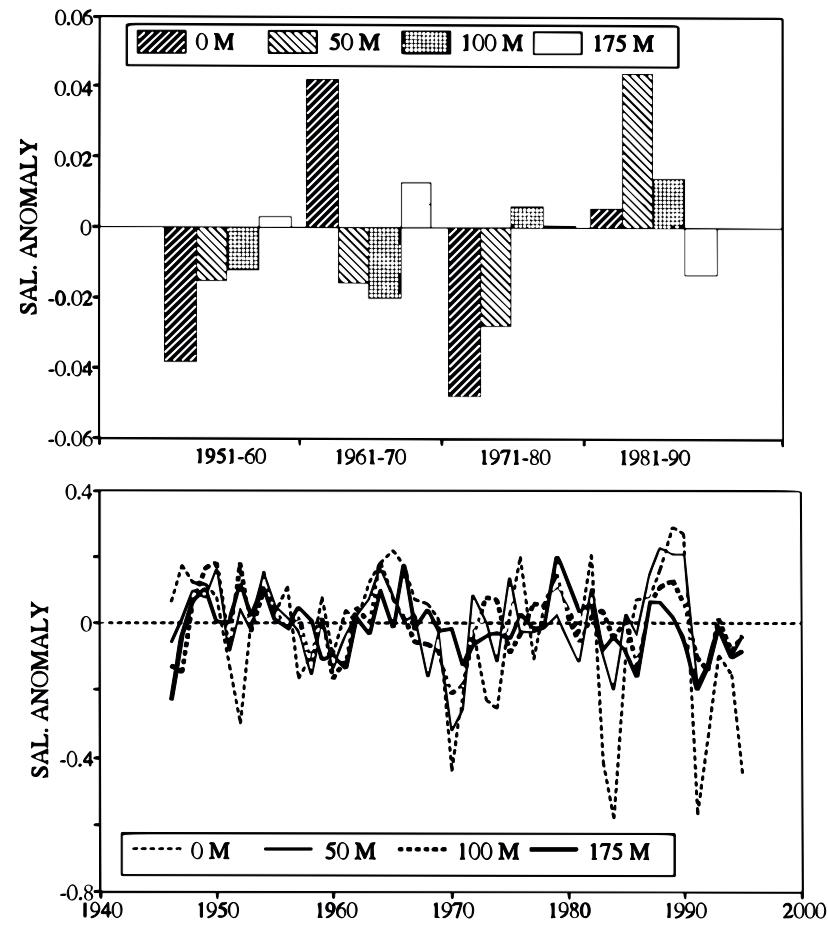

Fig. 22. The decadal (top) and annual (bottom) salinity anomalies at 0, 50, 100 and $175 \mathrm{~m}$ at Station 27.

Atmospheric cooling of the upper 100 to $200 \mathrm{~m}$ of water takes place in winter. In summer, solar heating and low salinity surface waters from ice melt form a shallow (30-40 m) upper layer that insolates the winter-cooled water below. On the Newfoundland Shelf this cold water mass lies above warmer water that has penetrated in from offshore. Because of the warmer water both above and below it, this layer has been called the CIL. Off Newfoundland, the CIL has been defined as waters with temperatures less than $0^{\circ} \mathrm{C}$ (Petrie et al., 1992). Time series of the cross-shelf areal extent of the CIL have been developed at standard transects. Although some differences do occur between different sections, the long-term trends are similar. The transect containing the most complete data is the summer occupation of the Bonavista Line.

Temperature data on the Bonavista Line are available since the late 1940s (Fig. 23). The decadal means show a pattern inverse to the temperature anomalies at Station 27, with a maximum in the 1980s (cold years) and a minimum in the 1960s (warm years). This is consistent with the close inverse association between CIL area and Station 27 temperatures found by Petrie et al. (1992). The CIL area varied greatly within the decade of the 1980s from low in the early years to the maximum recorded over the entire record in the mid-1980s. 

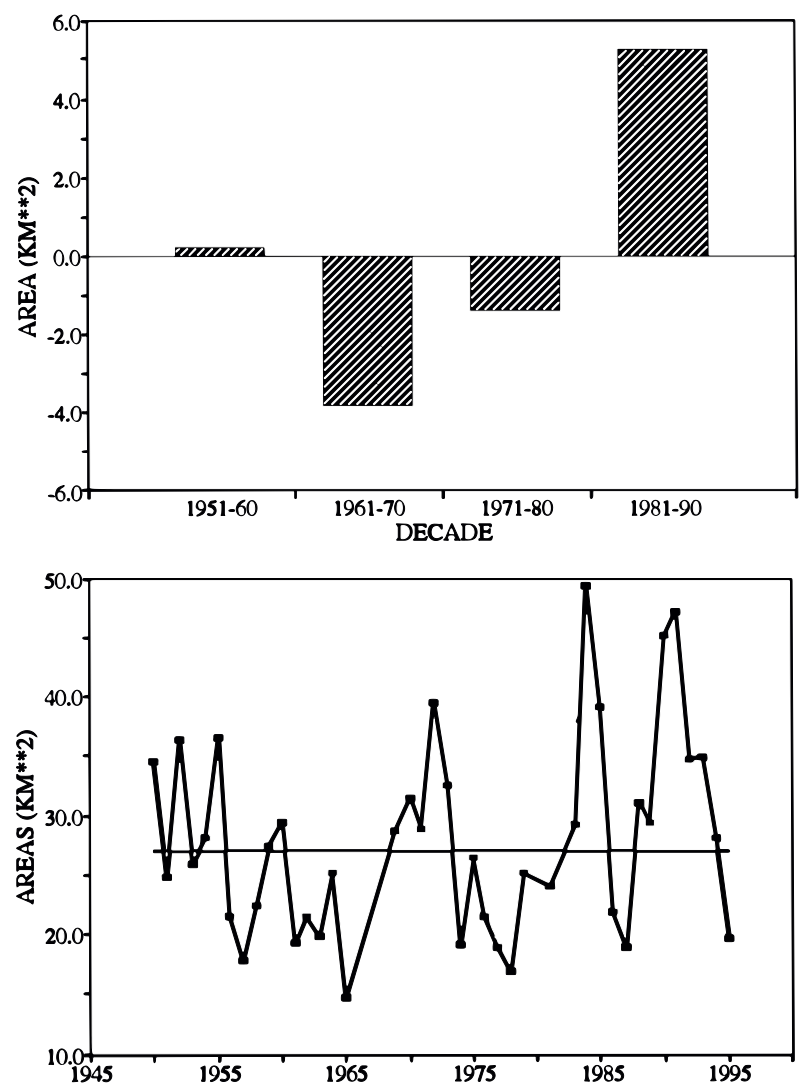

Fig. 23. The decadal anomalies (top) and annual values (bottom) of the areal extent of the CIL on the Bonavista Bay line in summer. The solid horizontal line denotes the 1961-90 mean.

The CIL area again decreased through to 1987 and increased to a peak in the early 1990s. This annual pattern is also inverse to Station 27 temperatures.

The mid-1980s and the early 1990s were times of cold sea temperatures and low salinity. They corresponded with cold air temperatures, strong winds and heavy ice suggesting the importance of atmospheric forcing as noted by Lazier (MS 1988), Drinkwater and Trites (1993), Colbourne et al. (1994) and Umoh et al. (1995). However, heat budget calculations show that local heat fluxes or those for the northern Newfoundland Shelf cannot explain the observed interannual variability at Station 27 or on the southeastern Grand Banks (Umoh et al., 1995). This suggests the importance of advection from farther upstream as the principal cause of the interannual variability. Myers et al. (1990) and Petrie et al. (1992) have shown that interannual salinity variability at Station 27 during the time of the seasonal salinity minimum is primarily due to ice melt from the Labrador Shelf and northern Newfoundland. Temperature events similar to those at Station 27 were observed in the 1980s and 1990s at Fyllas Bank but approximately 2 years earlier. This lag matches closely that found by Dickson et al. (1988) for the advection of the Great Salinity Anomaly from West Greenland to Newfoundland. Myers et al. (MS 1988) observed significant correlations between hydrographic properties on Fyllas Bank with those at Station 27 with a lag of approximately one and a half years and Stein (1993) found a strong correlation between both temperature and salinity on Fyllas Bank with the extent of the CIL off the Labrador coast. These studies indicate the importance of large-scale advection of water properties around the perimeter of the Labrador Sea. Still, the strong association between atmospheric conditions over the Labrador Sea and temperatures at Station 27 also support the notion of atmospherically forced hydrographic changes that are advected onto the Labrador Shelf and the Grand Banks from an as yet unidentified region upstream, perhaps the northern Labrador Sea, Davis Strait or Baffin Bay.

\section{Gulf of St. Lawrence (Divisions $4 T, R, S$ )}

Bugden (1991) investigated temperature conditions in the deep waters of the Laurentian Channel. Varying proportions of Labrador and western North Atlantic waters produced temperature changes at the mouth of the Channel that propagated slowly up-channel towards the St. Lawrence Estuary through a combination of advection and diffusion. He developed an index of temperature change using the 200-300 m average temperature from Cabot Strait. These data have been updated annually in the NAFO environmental overviews (e.g. Drinkwater et al., MS 1995). The 1980s was the warmest decade in the last 4 for the deep Cabot Strait waters (Fig. 24), an almost inverse pattern to temperatures observed at Station 27. Decadal temperatures had risen from the minimum in the 1960s. During the 1980s deep water temperatures were generally between 5.5 to $6.5^{\circ} \mathrm{C}$. They dropped rapidly in the early 1990s, returned to high levels and recently have fallen to near normal values. Bugden (1991) noted that the variability was controlled by the slope water temperatures at the mouth of the Laurentian Channel.

Additional temperature and salinity time series were developed for selected areas of the Gulf including the Esquiman Channel, western Cabot Strait and on the Magdalen Shallows from the historical database at BIO. The warm conditions observed during the 1980s in Cabot Strait extended into the Esquiman Channel at depths below $125 \mathrm{~m}$. Also similar to Cabot Strait, the waters cooled rapidly in the late 1980s and early 1990s but then rose. These results confirm the earlier conclusion of Bugden (1991) that the Cabot Strait index reflects temperature conditions in the deep channels of the 

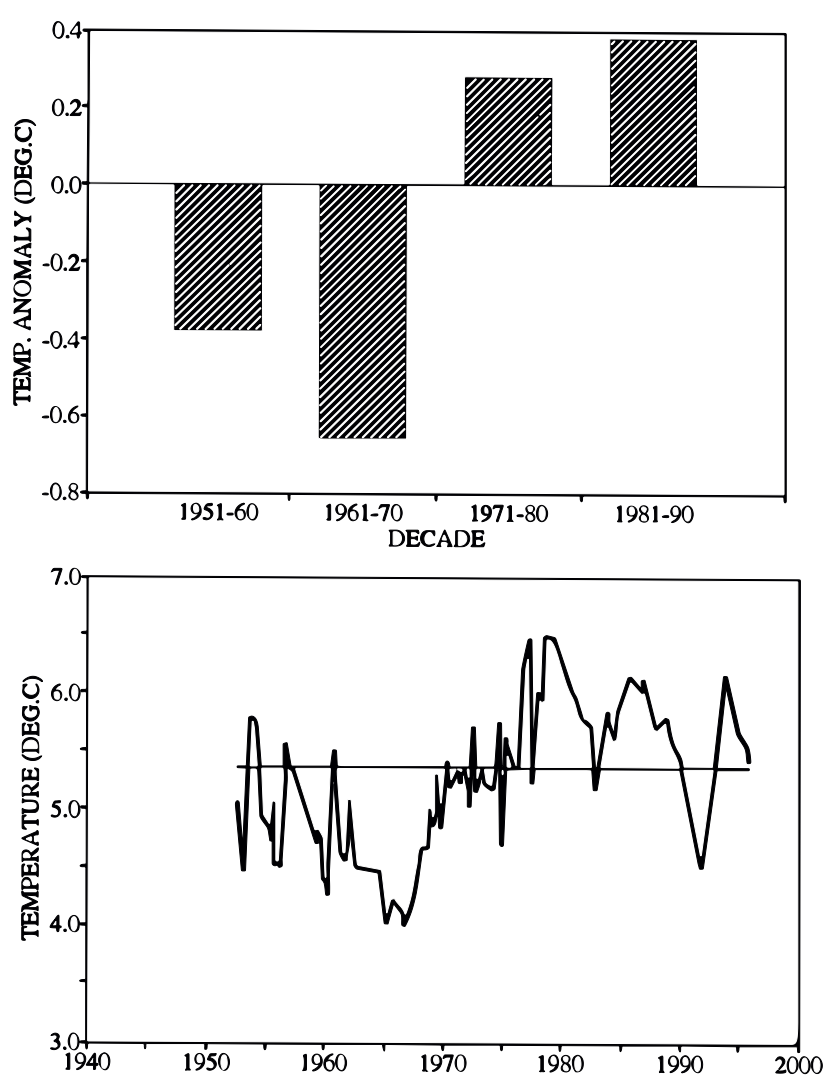

Fig. 24. The decadal (top) and annual (bottom) temperature in the 200 to $300 \mathrm{~m}$ depth layer in Cabot Strait. The solid horizontal line denotes the 1961-90 mean.

Gulf. The decadal temperature anomalies for the 1980s throughout the Gulf were above normal for the surface layers but near normal in the 50-100 m depth range, i.e. the CIL. The core temperature in the CIL abruptly declined in 1985, however, and has remained very cold through to the present (Gilbert and Pettigrew, 1996). These cold waters are believed to be principally a result of atmospheric cooling during the winter within the Gulf of St. Lawrence (Gilbert and Pettigrew, 1996).

\section{Scotian Shelf (Divisions $4 \mathrm{~V}, W, X$ ) and the Gulf of Maine (Subarea 5)}

Petrie and Drinkwater (1993) examined the lowfrequency variability in hydrographic properties of the waters on the Scotian Shelf and in the Gulf of Maine from 1945-90. The dominant feature was the cooling and freshening of the water from the early 1950 s to the mid-1960s with a rapid reversal into the 1970s. Analysis of data from Emerald Basin in the center of the Scotian Shelf revealed a strong similarity in the low-frequency trends throughout the water column and with other regions from the Laurentian Channel to the Middle Atlantic Bight. The interannual temperature variability could not be explained by local atmospheric heating (Umoh 1992). Instead they found the origin of the temperature and salinity changes lay in the slope waters along the continental slope and were advected onto the shelf through cross-shelf exchange, a hypothesis proposed earlier by Lauzier (1965). Petrie and Drinkwater (1993) went on to suggest that variations in the transport of the westward flow of the deeper (100-300 m) Labrador Current along the slope was the most likely cause of the observed changes in the temperature and salinity of the offshore slope waters and hence the source of the changes on the Scotian Shelf and in the Gulf of Maine. They found, based upon data collected by the US Coast Guard off the Grand Banks, that during the warm 1950s the geostrophic transport in the offshore Labrador Current was reduced whereas in the cold 1960s there was increased transport. A simplified mixing model based upon the differences in transport between the warm and cold years and a constant mixing rate could account for the observed changes in temperature and salinity at Cabot Strait, on the Scotian Shelf and in the Gulf of Maine. Advection from the Labrador Sea in terms of the volume of Labrador Current water rather than its T,S properties appears to play a very important role in the interannual variability of regions further south. The larger transport of the Labrador Current occurred during a warm period in the Labrador Sea. Increased geostrophic transport in the Labrador Current in warm Labrador Sea years (Iow NAO index) was also observed by Myers et al. (MS 1989).

The temperature anomalies in Emerald Basin are shown in Fig. 25. Note that they are 2 to 3 times the amplitude of those at Station 27 and the size of the anomalies are largest at depth. The cooling from the 1950s to the mid-1960s and the sharp rise into the 1970s is the dominant signal (Petrie and Drinkwater, 1993). During the 1980s the deeper waters (below $100 \mathrm{~m}$ ) were relatively warm while waters above $100 \mathrm{~m}$ were colder than the 1961-90 mean. Of particular note from the annual anomalies is that the temperature trends in the bottom waters (200 $\mathrm{m}$ ) and shallower seem to diverge around 1985 (Fig. 25). Prior to this time temperature anomaly trends were generally similar with depth but since then the bottom waters have been relatively warm whereas the upper $100 \mathrm{~m}$ have been cold, although in 1995 they warmed considerably. Drinkwater et al. (MS 1995) found significant cooling over the entire Scotian Shelf and into the Gulf of Maine, especially in the CIL between 50 to $100 \mathrm{~m}$ and in the near bottom waters in the northeastern Scotian Shelf. This cooling began around 1985 and continued through into the 1990s. Cold waters during this time were also observed on St. Pierre 

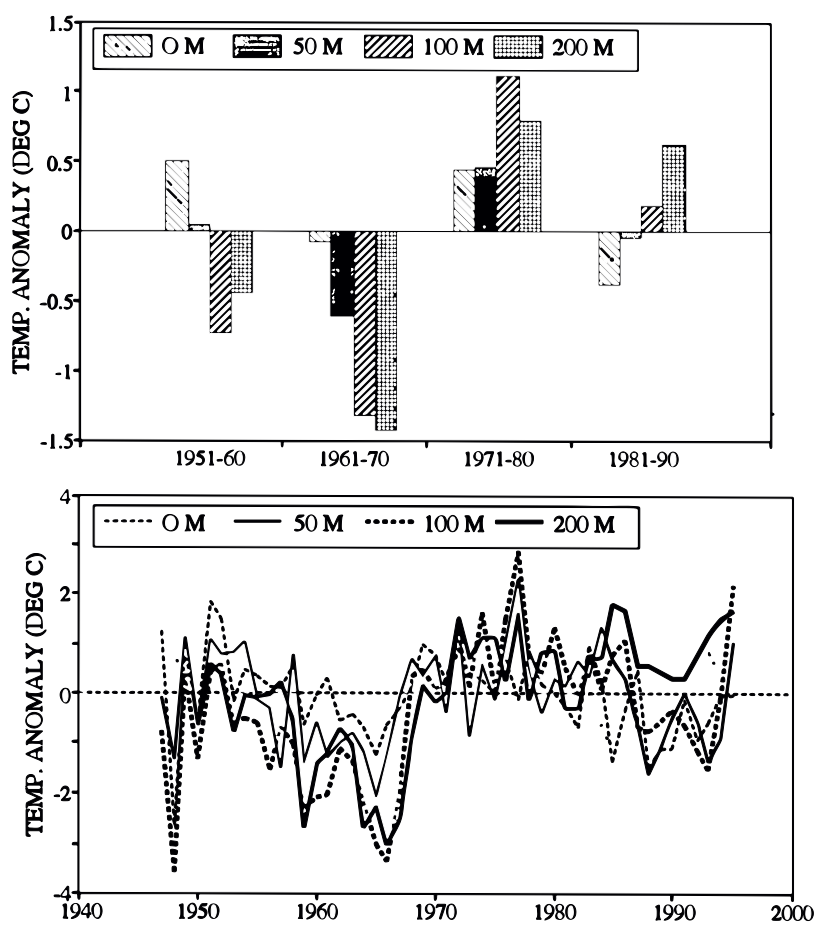

Fig. 25. The decadal (top) and annual (bottom) temperature anomalies at 0,50, 100 and $200 \mathrm{~m}$ in Emerald Basin.

Bank off southern Newfoundland and in the Gulf of St. Lawrence. The relative importance of advection versus local atmospheric forcing as the source of this cooling on the Scotian Shelf remains unresolved.

One of the longest operating offshore monitoring sites in the NW Atlantic is Prince 5 located at the mouth of the Bay of Fundy. Measurements began in the 1920s and are sampled once per month by scientists from the St. Andrews Biological Station. Strong tidal currents reduce vertical temperature and salinity gradients. Similarity of low-frequency changes between Prince 5 and other regions of the Gulf of Maine and on the Scotian Shelf have been noted by Lauzier (1965) and Petrie and Drinkwater (1993). This can also be seen by comparing Fig. 26 and 25. During the 1980s, Prince 5 temperatures have been above the 1961-90 mean but in general have been lower than temperatures attained in the 1970s. Cold conditions dominated the 1930s and 1960s with the warmest temperatures in the 1950s. Within the last decade temperatures through the water column were relatively warm but began to decline by the mid1980s. A large decrease was observed in the early 1990s. This decrease is part of a wide spread phenomenon over the eastern Gulf of Maine and at intermediate depths on the Scotian Shelf as
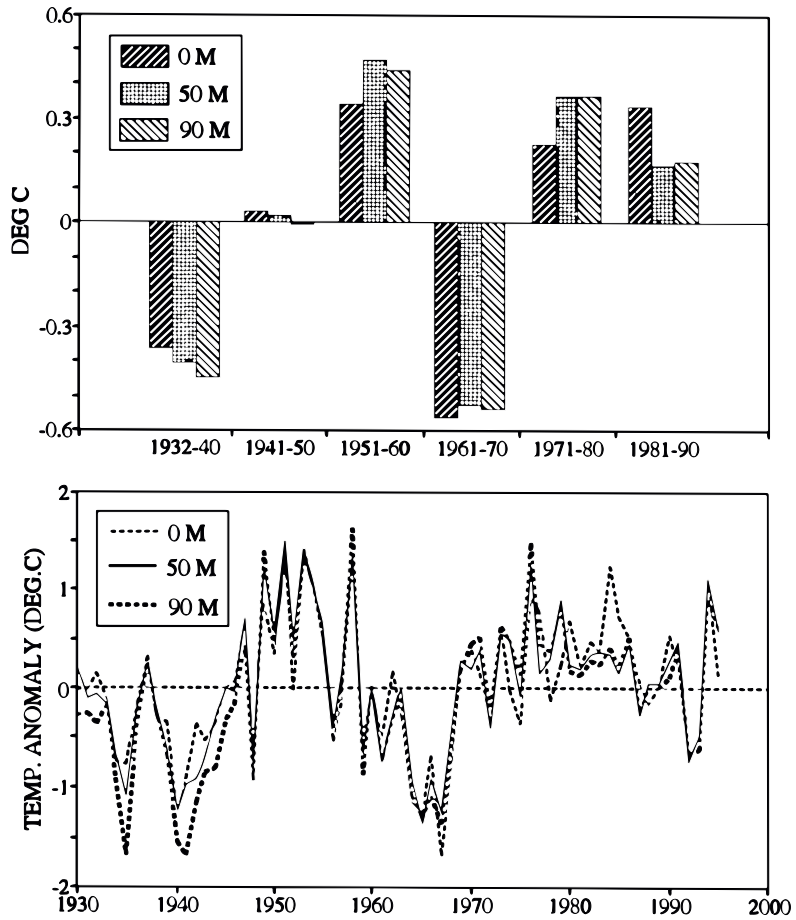

Fig. 26. The decadal (top) and annual (bottom) temperature anomalies at 0,50 , and $90 \mathrm{~m}$ at Prince 5.

discussed above. Temperatures rose rapidly in 1994 due to an influx of warm slope water into the Gulf of Maine (Drinkwater et al., MS 1995). Salinities in the 1980s were above the 1961-90 means but dropped relative to the 1970s (Fig. 27). Relatively fresh conditions at the mouth of the Bay of Fundy in the 1960s is similar to the Scotian Shelf and is believed to originate from fluctuations in the salinity of the offshore waters (Petrie and Drinkwater, 1993) rather than to the variability in the Saint John River discharge (Fig. 18). In the 1990s, salinity anomalies fell during the period of colder temperatures but rose with the increase in temperature.

\section{Middle Atlantic Bight (Subarea 6)}

Temperature conditions in the Middle Atlantic Bight from the 1960s to the late 1980s were described by Mountain and Murawski (1992) from measurements taken during spring and bottom-trawl surveys. They report high coherence between surface and bottom temperature anomalies and over geographic scales from Cape Hatteras to and including the Gulf of Maine. The late 1960s was the coolest period, the mid-1970s the warmest, while the late 1970s and early 1980s were of intermediate temperatures. Temperatures increased in the mid1980 s but did not attain those temperatures observed in the mid-1970s. Manning (1991) investigated salinity variability in the Bight from data 

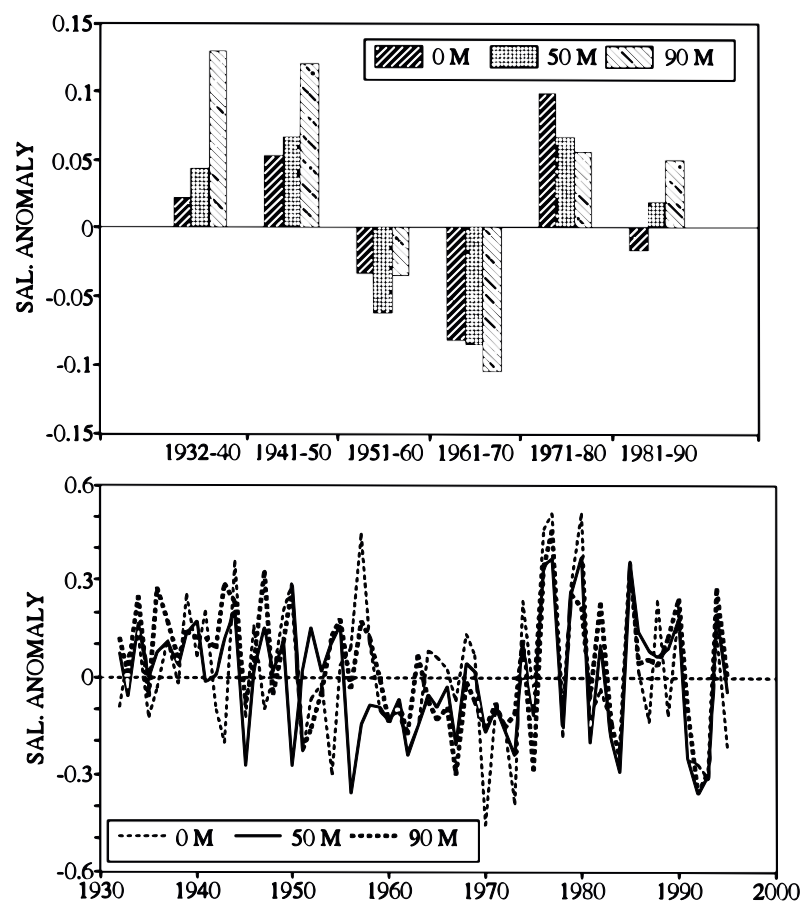

Fig. 27. The decadal (top) and annual (bottom) salinity anomalies at 0,50 , and $90 \mathrm{~m}$ at Prince 5.

collected between 1977-87. The shelf waters exhibited large interannual variations (range of 1 ) with low salinity in the late 1970s, 1984 and 1988 separated by years of relatively high salinity in 1981 and 1986. He found that river discharge from U.S. (the major rivers flowing into the Bight and the Gulf of Maine) and the Gulf of St. Lawrence (RIVSUM) plus precipitation accounted for $70 \%$ of the interannual changes in salinity. Mountain (1991), however, suggested that the hydrographic variability on the Bight was largely a result of changes in the amount of slope water that mixed with the shelf water. The waters on the Bight originate from cold, low salinity waters flowing south over the Scotian Shelf and the relatively warm, saline slope water. The latter enters the Gulf of Maine through the NE Channel and mixes with the Scotian Shelf waters as they circulate anticlockwise around the Gulf. The resultant water mass is eventually carried by the residual circulation onto the Bight where it continues its journey southward. Warm and saline conditions in the mid-1980s he attributed to the increased inflow through the NE Channel.

\section{Summary and Comments}

During the 1980s and 1990s:

1) The Icelandic Low and the Bermuda-Azores High intensified (high NAO index) resulting in stronger northwesterly winds to the
Labrador Sea and southerly winds to the Middle Atlantic Bight. The northwesterly winds carried cold Arctic air farther south which lead to the coldest decade this century over the Labrador Sea. In contrast, along the eastern U.S. seaboard the southerly winds brought warmer-thannormal conditions. From the Gulf of Maine to Newfoundland, air temperatures were near normal.

2) The cold air temperatures and strong northwesterly winds lead to greater areal extent of sea ice through increased ice formation and advection. The greatest ice area in 3 decades of records occurred in the 1980s and these severe ice conditions extended into the 1990s.

3) Off West Greenland oceanic temperatures averaged over the 1980s were near normal and similar to those during the 1960s and 1970s but well below the warm 1950s. This averaging masked a near decadal oscillation that is also observed in air temperatures. Salinities off West Greenland have risen over the past $30 \mathrm{yr}$, due most likely to changes in the source waters of the West Greenland Current.

4) On the Labrador and Newfoundland Shelves, including the Grand Bank, the waters were the coldest in 4 decades of records. There was also a larger amount of cold water as suggested by the areal extent of the CIL waters. The cold conditions have persisted into the 1990s. Cause of the cold waters is believed to be a combination of atmospheric cooling in winter and advection from West Greenland, although their relative importance is unknown.

5) In the deep waters of the Gulf of St. Lawrence, the Scotian Shelf and the Gulf of Maine temperatures during the 1980s were the warmest in the past 4 decades. These conditions are due to penetration of warm slope waters onto the shelves through channels and gullies.

6) While temperatures in the CIL from southern Newfoundland to the Gulf of Maine averaged for the 1980s were near normal, over most of this area temperatures fell dramatically around 1985 to below normal and have remained so through most the 1990s. In the Gulf of St. Lawrence this is attributed to local atmospheric cooling in the winter although the mechanisms in the other areas have not yet been established. 
Finally, two important breakthroughs are noted since the last decadal review (NAFO, 1982). First, past reviews (ICNAF, 1967, 1972; NAFO, 1982) concentrated primarily upon the SST records and lamented the lack of subsurface information (e.g. Trites, 1982). During the past decade, analysis of historical data plus the collection of additional subsurface information have added greatly to the description and understanding of the changes in the subsurface waters. Second, the importance of advection in controlling the long-term ocean temperatures in the shelf regions has been established throughout the NAFO region (Dickson et al., 1988; Myers et al., 1990; Mountain, 1991; Petrie et al., 1992; Petrie and Drinkwater, 1993; Umoh et al., 1995). In the Labrador Sea region, including the Grand Bank, it is variability in temperature and salinity characteristics of the upstream waters that is important whereas south of the Grand Banks it is the volume of Labrador Current water transported into the slope water that is more important than the change in the hydrographic properties themselves. By the time of the next decadal review it is anticipated that further advancements will allow us an even better description of the interannual variability. Of particular importance is sorting out the relative importance of local atmospheric forcing and advection. The former requires more heat budget studies such as that of Umoh et al. (1995). Also, great strides are being made in shelf circulation models and they are beginning to be used to investigate interannual variability in the circulation patterns. It is hoped that the results from such models may be able to be incorporated into the next decadal review of the physical environment.

\section{Acknowledgements}

I thank R. Pettipas and L. Petrie for their technical support in the preparation of this paper. B. Petrie, D. Lawrence, M. Stein and one anonymous reviewer provided valuable comments on an earlier draft of the paper. I greatly appreciate those who provided data including M.Stein and E. Buch (Fyllas Bank), S. Narayanan (Stn 27 of CIL area), I. Peterson and S. Prinsenberg (Newfoundland sea ice), U.S. Coast Guard (icebergs), P. Coté (ice duration), and F. Page (Prince 5). A debt of gratitude is also owed to those scientists, technicians and ships crew who are too numerous to list but who have collected and continue to collect the routine data upon which this review is based.

\section{References}

AGNEW, T. 1993. Simultaneous winter sea-ice and atmospheric circulation anomaly patterns. Atmosphere-Ocean, 31: 259-280.
ANDERSON, C. 1971. The flow of icebergs along the Canadian east coast. In Proceedings of the Canadian Seminar on Icebergs. Can. Dept. National Defence: 52-61.

BIGELOW, H.B. 1927. Physical oceanography of the Gulf of Maine. Fish. Bull. U.S., 40: 511-1027.

BUCH, E. 1994. A monograph on the physical oceanography of the Greenland waters. Royal Danish Administration of Navigation and Hydrography, Copenhagen, Denmark, 405 p.

BUCH, E. and M. STEIN. 1989. Environmental conditions off West Greenland, 1980-85. J. Northw. Atl. Fish. Sci., 9: 81-89.

BUGDEN, G. 1991. Changes in the temperature-salinity characteristics of the deeper waters of the Gulf of St. Lawrence over the past several decades, In The Gulf of St. Lawrence: small ocean or big estuary? J.-C. Therriault [ed.] Can. Spec. Publ. Fish. Aquat. Sci., 113: $139-147$.

COLBOURNE, E., S. NARAYANAN and S. PRINSENBERG. 1994. Climate change and environmental conditions in NAFO divisions 2J and 3NO. ICES Mar. Sci. Symp., 198: 311-322.

COTÉ, P. MS 1989. Ice limits eastern Canadian seaboard. Environment Canada, Ottawa. $39 \mathrm{p}$.

DICKSON, R.R., J. MEINCKE, S.-A. MALMBERG and A.J. LEE. 1988. The great salinity anomaly in the northern North Atlantic, 1968-82. Prog. Oceanogr., 20: 103151.

DRINKWATER, K.F. and R.G. PETTIPAS. 1993. Climate data for the Northwest Atlantic: surface wind stresses off eastern Canada, 1946-1991. Can. Data Rep. Hydrogr. Ocean Sci., 123: 130 p.

DRINKWATER, K.F. and R.W. TRITES. 1989. Overview of environmental conditions in the Northwest Atlantic in 1987. NAFO Sci. Coun. Studies 13: 27-40.

DRINKWATER, K.F. and R.W. TRITES. 1993. Overview of environmental conditions in the Northwest Atlantic in 1990. NAFO Sci. Coun. Studies, 19: 15-29.

DRINKWATER, K.F., E. COLBOURNE and D. GILBERT. MS 1995. Overview of environmental conditions in the Northwest Atlantic in 1994. NAFO SCR Doc., No. 43, Serial No. 2552, 60 p.

GILBERT, D. and B. PETTIGREW. 1996. Interannual variability (1948-1994) of the CIL core temperature in the Gulf of St. Lawrence. Spec. Publ. Can. J. Fish. Aquat. Sci., (in press).

ICNAF. 1967. Selected Papers from a Special Meeting of the Environmental Subcommittee, May 1967, on Fluctuations in Sea and Air Temperature in the ICNAF Area Since 1950. ICNAF Redbook 1967, (IV).

ICNAF. 1972. Symposium on Environmental Conditions in the Northwest Atlantic, 1960-1969. ICNAF Spec. Publ., 8.

KOLLMEYER, R.C., D.A. MCGILL and N. CORWIN. 1967. Oceanography of the Labrador Sea in the vicinity of Hudson Strait in 1965. U.S. Coast Guard Oceanogr. Rept., CG373-12, 92 p.

KOUTITONSKY, V.G. and G.L. BUGDEN. 1991. The physical oceanography of the Gulf of St. Lawrence: A review with emphasis on the synoptic variability of the motion. In The Gulf of St. Lawrence: small ocean or big estuary? J.-C. Therriault [ed.] Can. Spec. Publ. Fish. Aquat. Sci., 113: 57-90.

LAMB, P.J. and R.A. PEPPLER. 1987. North Atlantic Oscillation: concept and an application. Bull. Amer. Meteor. Soc., 68: 1218-1225. 
LAUZIER, L.M. 1965. Long-term temperature variations in the Scotian Shelf area, ICNAF Special Publ., 6: 807-816.

LAZIER, J.R.N. 1980. Oceanographic conditions at Ocean Weather Station Ship Bravo, 1964-1974. AtmosphereOcean, 18: 227-238.

LAZIER, J.R.N. 1988. Temperature and salinity changes in the deep Labrador Sea, 1962-1986. Deep-Sea Res., 35: 1247-1253.

LAZIER, J.R.N. MS 1988. Lower temperatures in the Labrador Current and in the atmosphere during the early 1970's and 1980's. NAFO SCR Doc. No. 77, Serial No. 1525, $19 \mathrm{p}$

LAZIER, J.R.N. and D.G. WRIGHT. 1993. Annual velocity variations in the Labrador Current. J. Phys. Oceanogr., 23: 659-678.

MALMBERG, S.-A. and S.S. KRISTMANNSSON. 1992. Hydrographic conditions in Icelandic waters, 19801989. ICES Mar. Sci. Symp., 195: 76-92.

MANNING, J. 1991. Middle Atlantic Bight salinity: interannual variability. Cont. Shelf Res., 11: 123-137.

MARKO, J.R., D.B. FISSEL, P. WADHAMS, P.M. KELLY and R.D. BROWN. 1994. Iceberg severity off eastern North America: its relationship to sea ice variability and climate change. J. Climate, 7: 1335-1345.

MOUNTAIN, D.G. 1991. The volume of shelf water in the Middle Atlantic Bight: seasonal and interannual variability, 1977-1987. Cont. Shelf Res., 11: 251-267.

MOUNTAIN, D.G. and S.A. MURAWSKI. 1992. Variation in the distribution of fish stocks on the northeast continental shelf in relation to their environment, 1980-1989. ICES Mar. Sci. Symp., 195: 424-432.

MYERS, R.A., S.A. AKENHEAD and K.F. DRINKWATER. MS 1988. The North Atlantic Oscillation and the ocean climate of the Newfoundland Shelf. NAFO SCR Doc. No. 65, Serial No. 1508, $22 \mathrm{p}$.

MYERS, R.A., S.A. AKENHEAD and K.F. DRINKWATER. 1990. The influence of Hudson Bay runoff and icemelt on the salinity of the inner Newfoundland Shelf. Atmosphere.-Ocean, 28: 241-256.

MYERS, R.A., J. HELBIG and D. HOLLAND. MS 1989. Seasonal and interannual variability of the Labrador Current and West Greenland Current. ICES C.M. DOC., No. C: $16,18 \mathrm{p}$.

MYERS, R.A., G. MERTZ and J.A. HELBIG. MS 1990. Long period changes in the salinity of Labrador Sea water. ICES. C.M Doc., C:21, $15 \mathrm{p}$.

NAFO. 1982. Symposium on Environmental Conditions in the Northwest Atlantic during 1970-79. NAFO Sci. Coun. Studies, $\mathbf{5}$

PETRIE, B. and C. ANDERSON. 1983. Circulation on the Newfoundland continental shelf. Atmosphere-Ocean,
21: 207-226.

PETRIE, B. and K. DRINKWATER. 1993. Temperature and salinity variability on the Scotian Shelf and in the Gulf of Maine 1945-1990. J. Geophys. Res., 98: 2007920089.

PETRIE, B., J.W. LODER, J. LAZIER and S. AKENHEAD. 1992. Temperature and salinity variability on the eastern Newfoundland shelf: the residual field. Atmosphere-Ocean, 30: 120-157.

PRINSENBERG, S. and I. PETERSON. 1994. Interannual variability in atmospheric and ice cover properties along Canada's east coast for 1962 to 1992. In IAHR 1994 Proceedings of the 12th International Symposium on Ice, The Norwegian Institute of Technology, Trondheim, Norway, 1: p. 372-381.

ROGERS, J. C. 1984. The association between the North Atlantic Oscillation and the Soutern Oscillation in the Northern Hemisphere. Mon. Wea. Rev., 112: 19992015.

SMITH, E.H. 1931. The Marion expedition to Davis Strait and Baffin Bay, 1928. U.S. Coast Guard Bull., 19(3): $1-221$.

SMITH, E.H., F.M. SOULE and O. MOSBY. 1937. The Marion and General Greene Expeditions to Davis Strait and Labrador Sea. U.S. Coast Guard Bull., 19(2): $259 \mathrm{p}$.

SMITH, P.C. 1978. Low-frequency fluxes of momentum, heat, salt and nutrients at the edge of the Scotian Shelf. J. Geophys. Res., 83: 4079-4096.

STEIN, M. 1993. On the consistency of thermal events in the East Greenland/West Greenland Current system and off Labrador. NAFO Sci. Coun. Studies, 19: 714.

SUTCLIFFE, W.H. Jr., R.H. LOUCKS and K.F. DRINKWATER. 1976. Coastal circulation and physical oceanography of the Scotian Shelf and the Gulf of Maine. J. Fish. Res. Board Can., 33: 98-115.

TRITES, R.W. 1982. Overview of oceanographic conditions in NAFO Subareas 2, 3 and 4 during the 1970-79 decade. NAFO Sci. Coun. Studies, 5: 51-78.

TRITES, R.W. and K.F. DRINKWATER. 1984. Overview of environmental conditions in the Northwest Atlantic in 1982. NAFO Sci. Coun. Studies, 7: 7-25

UMOH, J.U. 1992. Seasonal and interannual variability of sea temperature and surface heat fluxes in the northwest Atlantic, Ph.D. thesis, Dalhousie University, Halifax, N.S., Canada.

UMOH, J.U., J.W. LODER and B. PETRIE. 1995. The role of air-sea heat fluxes in annual and interannual ocean temperature variability on the eastern Newfoundland Shelf. Atmosphere-Ocean, 33: 531-568. 
